\title{
コロイド系粉体の凝集
}

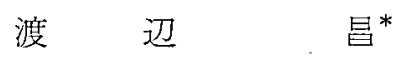

Akira Watanabe: The Coagulation of Colloidal Powders. The stability of hydrophobic colloids is mainly governed by the magnitude of the potential energy of repulsion due to the superposition of electrical double layers and van der Waals attraction between approaching particles. In the absence of potential barriers, every collision between particles leads to adhesion (rapid coagulation), and in the presence of potential barriers, the probability of collision is decreased, thus leading to slow coagulation. A quantitative theory was given by Reerink and Overbeek to describe the influence of the double layer thickness at constant Stern potential on colloid stability, a situation which occurs when indifferent inorganic electrolytes are added to sols. While, Ottewill, Rastogi and the present author gave a theory which treated the case where the change in the Stern potential occurs due to adsorption. An extended theory of coagulation was also given which treated the general case of changing ionic strength and potential.

The experimental verification of the theory thus obtained was carried out by measuring the coagulation kinetics of positively charged silver iodide sols spectrophotometrically. Electrokinetic measurements were also made by using ultramicroelectrophoresis. The agreement between the theory and experiments was very good and a reasonable value of the van der Waals constant was obtained. Experiments were also shown which were carried out by employing the twin dropping mercury electrodes polarized at various potentials in electrolytic solutions. The condition of coalescence of the mercury droplets, i.e. the relation between the ionic strength and the critical potential of coalescence, was proved to be in excellent agreement with the theory of coagulation of colloid particles. Thus, the interaction between finely dispersed particles in hydrophobic colloids is essentially the same as that acting between macroscopic mercury droplets.

(Received April, 10, 1964)

\section{I コロイド系の平衡}

一般に自由エネルギーが最小で自発的汇変化を起さな い系は平衡化ある之云われるが，とのとき如何なる变化 に関して平衡にあるかを指摘する必要がある。コロイド 分散系の年定性は凝集 (coagulation; flocculation) K ついての平衡の問題であるが，ふつうコロイド系が安定 (stable) と加不安定 (unstable) 之か云われるとき必 らずしも熱力学的に正しい表現であるとは云えない1.

系が熱力学的平衡にあるとき可逆コロイドと上ぶ22. 界面活性剂のミセルをふくんだ溶液（会合コロイド）, 蛋白やゴムなどの天然高分子やポリスチレンなど多くの 合成高分子の溶液がこれに属する，乙の系は親液性— 分散媒が水のときは親水性——ロロイドも呼ばれ，分 散相粒子間於よび分散媒粒子間の引力に比較して, 分散 相粒子と分散媒粒子との相互引力が非常に大きい系であ る. 従ってての系では溶媒和が安定性の主要な原因とな っている.
これに反して AgI や金のゾルなどの疎液性コロイド は髙力学的には真の平衡状態ではなく, 不可逆コロイド と上ばれる3゙。すな放ち，乙の系を長時間放置す机ば必 らず凝集して最終の平衡状熊（二相分離）に至る，ふつ う安定な䟽液性コロイドと呼ばれる状態は，凝集速度が 非常に小さくて 最終平衡状態に達するための時間が， 観測の時間尺度に比して非常に長い場合に外ならない (frozen equilibrium ${ }^{1)}$ ). 従って, 疎液性コロイドの安 定㥏はむしろ相対的な性質で。凝集速度が小さい系はい わゆる安定性が高いわけである。この種の系では熱力学 的平衡論ではなく，分散相粒子の動力学的挙動の考察が 重要となる。

系が可逆コロイドか，あるい位安定な不可逆コロイド かの判定は必らずしも容易ではない，溶質が溶媒と接し たとき自発的に分散するなら可逆コロイドである。 そう でないときは, 非常に僅かなエネルギー差が問題となり

* 京都大学化学研究所 高棁市大学町 
うるから，如何に静かに行なっても筧拌をしたりすると 自発的分散之は見なされない，一方，雪解質などの凝集 剂を加えて凝集現象が見られるときは可逆コロイドでは ない，勿論，采の平衡を移動させるような添加物を用い た埸合は別である。

コロイド粒子の運動では主として Brown 熱運動が問 題となるが，ふつうの条件では粒子間力のない之きの Brown 運動比よる粒子の衝突回数は大きな谊を示す． 従って不可逆コロイドの努定性の説明には，粒子が非 常に接近する之 van der Waals 引力が働くが, 遠方 では斥力が衔くと考え枚ばならない，たとえば $\mathrm{KI}$ と $\mathrm{AgNO}_{3}$ との水溶液を混合して $\mathrm{AgI}$ をつくるとき, 反 応物の何れかが過剩なときにのみ安定な AgI ゾルがで きる。乙机は $\mathrm{Ag}^{+}$又は I- イオンが $\mathrm{AgI}$ 精子に吸着 して正又は負の带電を与え，乙のために精子間㳻電斥 力が㗢くからである. 粒子表面の電荷に対応して, 界面 の溶液側にはてれを中和するために反対符号のイオンの 過剩と同符号イオンの不足が現われる(電気二重屠). 促って上述の静電质力は粒子表面電荷のみでなく, 分散 媒のイオン强度にも著しく依存する。電解質や界面活性 剂の添加似よって起る電気二重層構浩の变化, およびて れの疎液性コロイドの安定性に及ぼす影響を論ずるのが 本綜説の目的である.

\section{II 急速 凝 集}

最も簡単なのは粒子間暞互作用がない場合で，この上 きの凝集を急速凝集 (rapid coagulation) という”. Smoluchowski4) はこれにたいする理諭を与えた。

任意のコロイド粒子（半径 $a$ ) の中心を原点にとり， Brown 運動炕よって单位時間にその衙突半径 $2 a$ の球 面汇衝突する粒子数 (flux) $J r$ を計算する。 下添字 $r$ は急速凝集を意味する．系は原点につき球対称だから， 中心からの距離 $r$ の点での時刻 $t$ における単位体皘あた りの粒子数 $N(r, t)$ は Fick の自由拡散微分方程式を 満足する5).

$$
\frac{\partial N(r, t)}{\partial t}=\frac{D^{\prime}}{r^{2}} \frac{\partial}{\partial r}\left[r^{2} \frac{\partial N(r, t)}{\partial r}\right]
$$

ここに $D^{\prime}$ は原点の粒子にたいする他の粒子の相対的拡 散定数で，中心粒子の Brown-運動を考虑に入れると， 巨視的拡散定数を $D$ として ${ }^{3)}$,

$$
D^{\prime}=2 D
$$

系に多量の電解質を加えると粒子間静電斥力が除かれ て急速凝集加起る (V参照)。添加した時刻を $t=0$ に とると初期条件は

$$
t=0, r>2 a \text { のとき } N(r, 0)=N
$$

ここに $N$ は $t=t, r \rightarrow \infty$ での平均 bulk 粒子浱度であ る。他の粒子が中心粒子に衝乫すると凝集が起るから境
界条件は

$$
t>0, r=2 a \text { のとき } N(r, t)=0
$$

式 (3) と (4) を満足する(1) の解蚮式で与えられる，

$$
N(r, t)=N\left\{1-\left(\frac{2 a}{r}\right) \operatorname{erfc}\left(\frac{r-2 a}{2 \sqrt{D^{\prime} t}}\right)\right\}
$$

ここに

$$
\operatorname{erfc}(\lambda)=1-\operatorname{erf}(\lambda)=\frac{2}{\sqrt{\pi}} \int_{\lambda}^{\infty} \exp \left(-y^{2}\right) d y
$$

従って(5)より

$$
\begin{aligned}
J_{r} & =4 \pi(2 a)^{2} D^{\prime}[\partial N(r, t) / \partial r]_{r=2 a} \\
& =8 \pi a D^{\prime} N\left(1+\frac{2 a}{\sqrt{\pi D^{\prime} t}}\right)
\end{aligned}
$$

$t \gg 4 a^{2} / \pi D^{\prime}($ ふつうのコロイド系では十分短時間であ る）では(7)の插弧内の第2 項（過渡現象の項）は1に たいして無視でき，次の定常状態の flux がえられる，

$$
J_{r}=8 \pi a D^{\prime} N=16 \pi a D N
$$

系のすべての稙子について (7) 又は (8)の flux が考兄ら 机る，従って采全体につき単位体積中の粒子分衙突に上 って消失する速度 $-d N / d t$ は $J r$ と $N$ の積の $1 / 2 て ゙$ 与えられる. 多くの教科書住いいて係数 $1 / 2$ がかかって いないが゙，乙㣗は誤と思う。何故なら $J_{r} N$ では衝突 が 2 度訫算に入るからである. かくて定常状態では

$$
-d N / d t=8 \pi a D N^{2} \equiv k_{r} N^{2}
$$

すなわ卢急速凝集蛙 2 分子反応で，速度定数 $k_{r}$ は次式 で与えられる，

$$
k_{r}=8 \pi a D
$$

Einstein ${ }^{6)}$ によると各粒子が運動するときのまさつ抵 抗 $f$ は次式で与えられる,

$$
f=6 \pi \eta a=k T / D
$$

$\eta$ は媒質の粘度， $\boldsymbol{k}$ は Boltzmann 定数，Tは絶対温 度である. 10 に代入すると，

$$
k_{r}=4 \boldsymbol{k} T / 3 \eta
$$

$25^{\circ} \mathrm{C}$ の水では㳄の値となる,

$$
k_{r}=5.4 \times 10^{-12} \mathrm{~cm}^{3} \mathrm{sec}^{-1}
$$

\section{III 電気二重層}

\section{1 粒子の帯電}

㔻白粮子が溶液相己接する之 carboxyl や amino 基 などの解離平衡によって粒子は正や負に带電する。また $\mathrm{AgI}$ 粒子の之きには溶液中の $\mathrm{Ag}^{+}$又は $\mathrm{I}^{-}$イオンの吸 着によって帯電が起る。

たとえば正の $\mathrm{Ag} I$ 結昆を考えよう ${ }^{79} . \mathrm{Ag}^{+}$イオン の吸着によって電気的中性が局部的に乱されると，さら に $\mathrm{Ag}^{+}$イオンが吸着するのが抑えられ，一方 $\mathrm{Ag}^{+}$イ オンの離脱が容易になる．從ってとの吸着平衡は表面之 
溶液内部での $\mathrm{Ag}^{+}$イオン濃度の比のみではなく，粒子 表面の電位 $\psi_{0} に$ 娄侬存する。（下添字 0 は表面での值を 示す。）とれはイオンをふくむ平衡論に捄いては化学ポ テンシャルではなくして電気化学ポテンシャルを用いて 議論が進妨れるのと同じである7 . かくて溶液の $\mathrm{pAg}$ （すなわち $-\log \left[\mathrm{Ag}^{+}\right] ）$ を变化させると $\mathrm{Ag}^{+}$イオン の吸着量が変化し，これ行従って $\psi_{0}$ 屯变化して最終の 平衡に達する。

この系に $\mathrm{NaNO}_{3}$ のような無関係塩（又は支持湓とも 云う）を加える之電気二重層の厚さ汃低下し，もし表面 電荷密度が一定なら電位 $\psi_{0}$ 汃低下するだろう。 これは 二重層の压縮によって電気容量が増大するから，同じ電 気量汶対して電位が低下すると考えればよい，ての結果 $\mathrm{Ag}^{+}$イオンの吸着が進んで表面電荷が増大し，乙れに よって電位 $\psi_{0}$ 加増大して平衡が回復さ机る. 汃くて pAg によって規定されるのは表面の電位 $\psi_{0}$ であり， 電荷は $\psi_{0}$ を一定に保つべく変化する，従って，AgI 表面に対して $\mathrm{Ag}^{+}$又は I- イオンは電位決定イオン (potential determining ion) であり, $\left[\mathrm{Ag}^{+}\right]\left[\mathrm{I}^{-}\right]=$ $10^{-16}$ によって pAg と pI は互に従属している，蛋白 では $\mathrm{H}^{+}$又は $\mathrm{OH}^{-}$イオンが電位決定イオンになって いる.

\section{2 電気二重層}

電気的中性の原理 ${ }^{7)}$ から，带電表面近くの溶液相には 表面電荷を中和する対イオンが存在するはずである。乙 の上きのイオンの分布老考えう。.

たとえは負に带電したガラス面は，溶液中にカチオ ン性界面活性物質があるならその特異吸着（specific adsorption）を起し，いわゆるStern 吸着層が形成さ 礼る ${ }^{8}$. この現象は無機イオンでむ起り，又界面活性が 十分大きいなら表面と同符号のイオンのときでさえ起 る ${ }^{14,16)}$. たとえば $\mathrm{AgI}$ の当量点が $\mathrm{pAg}=\mathrm{pI}=8$ であ るのに, AgI サスペンジョンの等電点が $\mathrm{pAg}=6$ であ

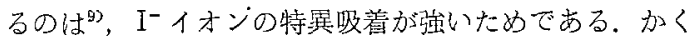
て AgI 固体表面, 或は他の固体表面, には一般に無機 イオンの特異吸着によるStern 吸着層が存在すると考 えられている。

Stern層につづいて溶液内部に向っていわゆる GouyChapman の拡散二重層 (diffuse double layer) 加 形成される ${ }^{10,111}$. この層でのイオンの分布ば静電力子熱 運動との均合に対応して形成されるもので, Stern 層の 近くでは対イオンの過剩之同符号イオンの不足が見ら れ，この層より遠ざかるにつれて正上負のイオンの電荷 が等しくなるような挖散的な性質の分布を示す。ただ， 対イオンと同符号イオンには本質的な差異がある。すな わち対イオン濃度は，体積効果を考えないなら，bulk 濃度の何倍にも増大することがでさ，これによる screening 效果（表面電荷の中和）は非常に有効である。し
かし同符号イオン濃度はゼロ以下には低下できないか ら，その不足による screening 效果には限度がある。 特に表面の電位 $\psi_{0}$ が大きいコロイド采では対イオンに 比較して同符号イオンの screening 效果は無視できる のが普通である。（例えば Schulze-Hardy の法則 V・3 参照)

Stern 層と拡散二重層とを総括して界面電気二重層 (Interfacial electrical double layer) とよふふ:12-16). 溶液 bulk の電位をゼ口とし，表面の電位を $\psi_{0}$, Stern 闃の電位を $\psi_{1}$ とすると，電気二重層内での静電位 $\psi$ は 表面加らの距離 $x$ の関数として Fig. 1 のような形をむ つ. A汶対イオンの特異吸着が少しの場合，Bは表面電 荷がちょうど中和された場合，Cは対イオンの特異吸着 が表面電荷を上回加った場合である。

\section{3 昖散二重層理論}

拡散二重層の理論は強電解質理諭 ${ }^{173}$ と本質的には同じ で, Gouy ${ }^{11)}$ と Chapman ${ }^{10)}$ は Debye, Hückel より

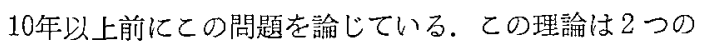
基本式に基づいており，その第1は Poisson 式である.

$$
\nabla^{2} \psi=-4 \pi \rho / \varepsilon
$$

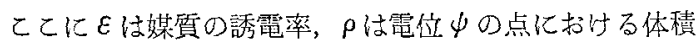
電荷密度である。特に一次元（带電無限平面）では

$$
d^{2} \psi / d x^{2}=-4 \pi \rho / \varepsilon
$$

$\rho=0$ なら $d^{2} \psi / d x^{2}=0$, すなわ電位は直程的に变化す る. $\rho \neq 0$ なら $\psi$ vs. $x$ は曲線で, 乙れは溶液内にイオ ンが多いほど screening 効果が大きいとと（III·2 参 照）を数式的に表現したもので，Coulomb の法則に外 ならない。

第2 の基本式は Boltzmann 分布で，熱運動を行な っているイオンが点 $x$ 亿存在する確率を与える. 従っ て点 $x$ での電荷密度 $\rho$ はこの点での $i$ イオンの濯度 $n l$ $\left(1 \mathrm{~cm}^{3}\right.$ あたりの個数）とそのイオンの電荷 $z \boldsymbol{e} \boldsymbol{e}$ との積 の総和で与えられる,

$$
\rho=\sum_{i} z_{i} \boldsymbol{e} n_{l} \cdot \exp \left(-z_{l} \boldsymbol{e} \psi / \boldsymbol{k} T\right) .
$$

$\boldsymbol{e}$ は電子電荷， $z_{l}$ は $i$ イオンの符号をふくめた原子価で ある。

対称 $z-z$ 洒電解質のときは

$$
\left|z_{+}\right|=\left|z_{-}\right|=z, \quad n_{+}=n_{-}=n
$$

とおくと式 (15)，(16)より

$$
d^{2} \psi / d x^{2}=\kappa^{2} \sinh (z \boldsymbol{e} \psi / \boldsymbol{k} T)
$$

ここに

$$
\begin{array}{r}
\kappa^{2} \equiv 8 \pi n \boldsymbol{e}^{2} z^{2} / \varepsilon \boldsymbol{k} T \propto \mu \\
\mu=\frac{1}{2} \sum_{i} z_{i}{ }^{2} c_{e}
\end{array}
$$

$\mu$ はイオン強度, $c_{e}$ は電解質濃度 $(M / 1)$ である。 

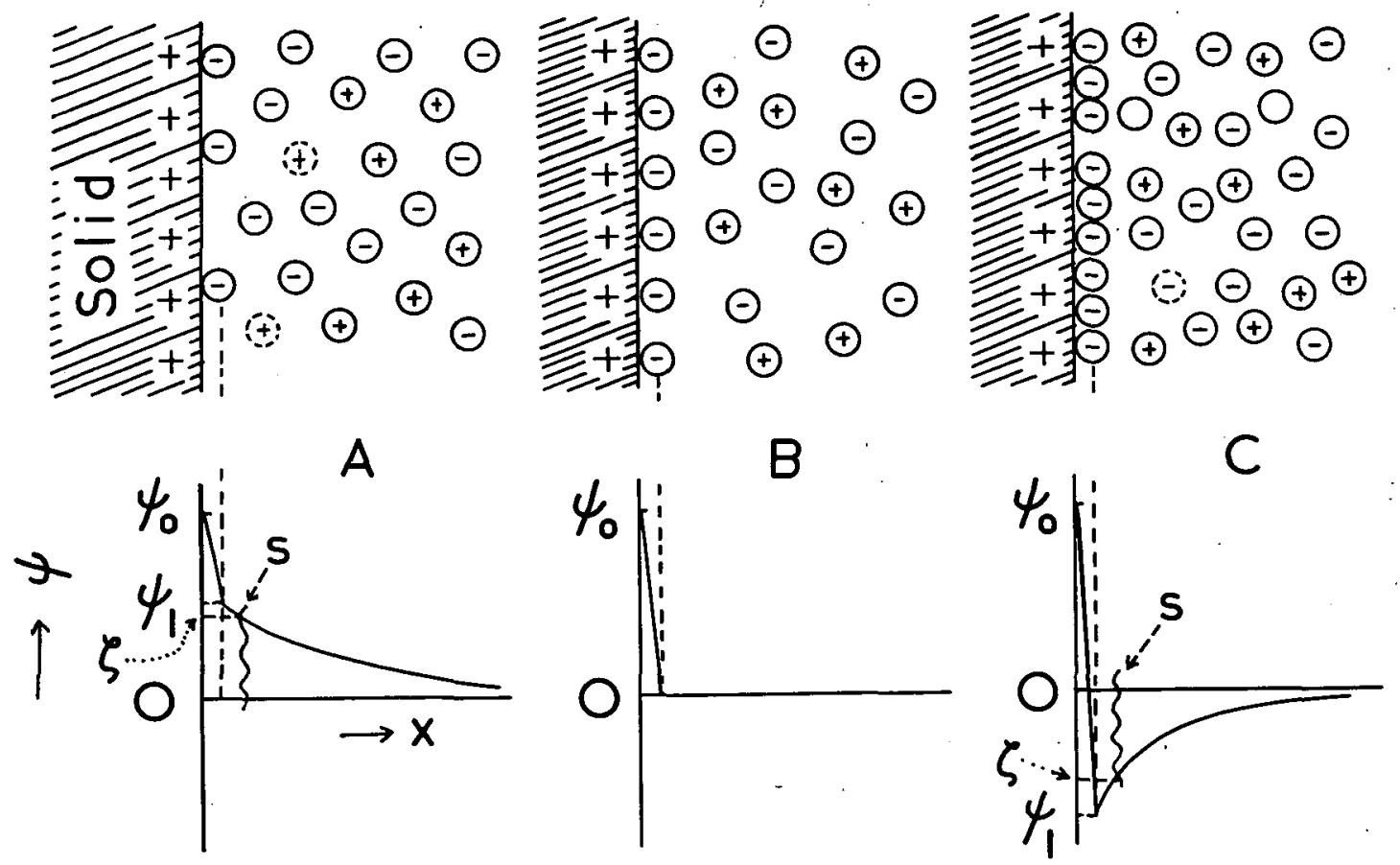

Fig. 1 The Stern pictures for interfacial electrical double layer, in the presence of small (A), medium (B) and large (C) specific adsorption of oppositely charged ions.

$\oplus$ cations; $\Theta$ anions; $\Theta$ deficit of cations; $\Theta$ deficit of anions; $s$, the slipping plane for electrokinetic phenomena.

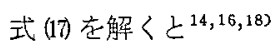

$$
\ln \frac{\exp (\boldsymbol{z e} \psi / 2 \boldsymbol{k} T)-1}{\exp (z \boldsymbol{e} \psi / 2 \boldsymbol{k} T)+1}=-\kappa x+\text { 定数 }
$$

特に $x=0$ で $\phi=\psi_{1}$ だから（Stern 層の愿さは無視す る), (19)より

$$
\psi=\frac{2 \boldsymbol{k} T}{z \boldsymbol{e}} \ln \frac{1+\gamma \exp (-\kappa x)}{1-\gamma \exp (-\kappa x)}
$$

ここに

$$
\gamma=\frac{\exp \left(z \boldsymbol{e} \psi_{1} / 2 \boldsymbol{k} T\right)-1}{\exp \left(z \boldsymbol{e} \psi_{1} / 2 \boldsymbol{k} T\right)+1}
$$

式(20)が求める $\psi(x)$ の関数形である. Debye 近似 $z e \psi_{1} /$ $\boldsymbol{k} T \ll 1\left(z=1\right.$ では $\left.\psi_{1} \ll 25 \mathrm{mV}\right)$ では $\gamma \rightarrow z e \psi_{1} / 4 \boldsymbol{k} T$ 乙 なり，(20) は次の形をとる，

$$
\phi=\psi_{1} \exp (-\kappa x)
$$

すなわち，1/cは電位が $\psi_{1} の 1 / e$ ( $e$ は自然対数の底) に低下する距離を示し二重層の厚さよよばれる． $25^{\circ} \mathrm{C}$ の水浴液では

$$
1 / \kappa \cong 3 \times 10^{-8} / z \sqrt{c_{e}}
$$

となり[式 (18) 参照], $z=1, c_{e}=0.1 \mathrm{M}$ で $10 \AA, 0.001 \mathrm{M}$ で $100 \AA, 10^{-5} \mathrm{M}$ で $1000 \AA$ となる。

元来 Debye-Hückel 近湖は非常にうすい溶液中の小 さなイオン間の相互作用の解析で導かれた理論であり， 帯電量, 従って Stern 電位 $\psi_{1}$, の大きいコロイド粒子
ではふつうとの近似式 (22) は妥当でない，粒子間距離が 十分大きく $\kappa x \gg 1$ とおけるときは，式 (20) は任意の $\psi_{1}$ 值に対して次の簡単な形になる,

$$
\psi \cong(4 \boldsymbol{k} T \gamma / z \boldsymbol{e}) \exp (-\kappa x)
$$

この式においても $1 / \kappa$ は二重層の厚さを示す parameter と考えられる.

球形粒子では半径 $a$ と二重層の厚さの比 $\kappa a$ が拡散二 重層内での曲率の尺度を表放す。 $\kappa a>10$ なら平面， $\kappa a<1 / 10$ なら点電荷と考えてよい. 一般に PoissonBoltzmann 式は(17)の代りに次の形をとる,

$$
\frac{d^{2} \psi}{d r^{2}}+\frac{2}{r} \frac{d \psi}{d r}=\kappa^{2} \sinh \frac{\boldsymbol{z e} \psi}{\boldsymbol{k} T}
$$

との式の explicit な解はえられないが，電子計算機に よる計算值のぼう大な表が与えられている ${ }^{19)}$. DebyeHückel 近似 $z \boldsymbol{e} \psi_{1} / \boldsymbol{k} T \ll 1$ では簡単な形の解がえられ 万,

$$
\psi=\psi_{1} \cdot \frac{a}{r} \cdot \exp [-\kappa(a-r)]
$$

ふつうの目的に対してはこの式で定性的には十分であ る.

式 (14)，(15)，(16)の仮定については種々検討すべき点が 多い20). たとえば電場が強くなったときの跒電飽和現 象 $^{21-23)}$ ，イオン濃度が高くなったときの体榬効果 ${ }^{24-26)}$ 
などは二重層の顸密な理論的考察においては無視するて とができない.

\section{Stern 層の理論}

表面への吸着力（静電引力， van der Waals 引力， 化学結合力など）が大きいと対イオン，そして時には同 符号イオン，の特異吸着によって表面に compactな吸 着層が形成される8 . 著者による一般化された Stern 層 の理論によると ${ }^{27)}$ ，単(位界面積あたりの吸着イオン数 $\nu$ は次式で与えられる，

$$
\begin{aligned}
& \nu=\frac{\nu_{m}}{1+(1 / \chi) \exp (\Delta \bar{G} / \boldsymbol{k} T)} \\
& \Delta \bar{G}=\Delta G+z \boldsymbol{e} \psi_{1}+b{\psi_{1}}^{2}
\end{aligned}
$$

ここに $\nu_{m}$ は吸着 site 数 $\left(\mathrm{cm}^{-2}\right), \chi$ は吸着する物質 のモル分率， $\Delta \bar{G}$ はその電気化学的吸着自由工ネルギー で， $\Delta G$ はその化学的項, $z e \psi_{1}$ は静電効果, $b \psi_{1}{ }^{2}$ は分 極効果を示方項である ${ }^{27,28)}$. 式 (26) および電気的中性の 原理，拡散二雷層の理論を用いて Stern 電位 $\psi_{1}$ を計算 することができる。

いま濃度 $c_{e}(\mathrm{M} / 1)$ の 1-1 価支持電解質溶液加固相 と接したときのStern 電位を $\psi_{1} *$ とし，乙れに濃度 $c(\mathrm{M} / 1)$ の界面活性剂イオン（符号をふくめた原子価を $z$ とする）を添加したとき，その特晎吸着によって Stern 電位が $\phi_{1}$ に変化したとすると平面（一次元）では次式 が導加礼る

$$
\begin{aligned}
\psi_{1} & =\frac{2 \boldsymbol{k} T}{\boldsymbol{e}} \sinh ^{-1}\left\{\sqrt { \frac { c _ { \boldsymbol { e } } } { c + c _ { e } } } \left(\sinh \frac{e \psi_{1} *}{2 \boldsymbol{k} T}+\right.\right. \\
& \left.\left.+\frac{\boldsymbol{z} \boldsymbol{e} \nu_{m}}{2} \sqrt{\frac{2 \pi \cdot 1000}{c_{e} \varepsilon \boldsymbol{k} T \boldsymbol{N}}} \cdot \frac{k c}{1+k c}\right)\right\}
\end{aligned}
$$

$\varepsilon$ は媒質の誘電率, $\boldsymbol{N}$ は Avogadro 数である. 又 $k$ は 吸着の平衡定数で $\Delta \bar{G}$ 之次の関係を屯つ,

$$
k=\exp (\Delta \bar{G} / \boldsymbol{k} T) / 55.6
$$

Debye-Hückel 近似 $\left(\boldsymbol{e} \psi_{1} \ll \boldsymbol{k} T\right.$ ，即ち $\left.\psi_{1} \ll 25 \mathrm{mV}\right)$ で は $\sinh y \cong y$ とおけ，(28) は次の形となる。

$$
\psi_{1}=\sqrt{\frac{c e}{c+c e}}\left(\psi_{1}^{*}+\frac{k k^{\prime} c}{1+k c}\right)
$$

ここ

$$
k^{\prime}=z \nu_{m} \cdot \sqrt{2 \pi \cdot 1000 \boldsymbol{k T} / \mathcal{E}_{e} \boldsymbol{N}}
$$

電気泳動では球面での式が必要である。この上きは厳 密な解は求められていないが( 3 参照), Debye-Hückel 近似では次式方導かれるる20,30，

$$
\begin{aligned}
& \psi_{1}=\sqrt{\frac{c e}{c+c e}}\left(\psi_{1} *+\frac{k k^{\prime \prime} c}{1+k c}\right) \\
& k^{\prime \prime}=4 \pi a e z \nu_{m} / \varepsilon(1+\kappa a)
\end{aligned}
$$

ここに $a$ は球の半径, $1 / \kappa$ は重層の厚さである[式 (18)]. この式 (33) で $a \rightarrow \infty$ と执くと(31)がえられる.

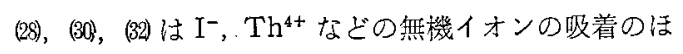

加, dodecylsulphate とか dodecylpyridinium など のアニオン性やカチオン性の界面活性剤イオンについて も用いることができる。さらに表面の遊離基での対イオ ン結合 (counter ion binding) においてす適用可能で (VI·4参照)，乙の場合には $\nu_{m}$ は遊離想の数， $\Delta \bar{G}$ は 電気化学的結合自由エネルギーを表わす。

Stern 層の棈造については，界面における水双極子の

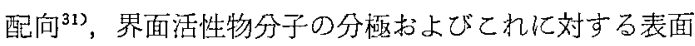
の電位の効果 ${ }^{28)}$, 吸着イオン半径およびその水和度の効 梁 $^{14,16,323}$ ，なよ゙興味ある問題が沢山あり，水銀電極によ る電気二重層の研究はこ机に刘して有益な知見を提供し ている ${ }^{16)}$.

\section{5 イオン強度関する注意}

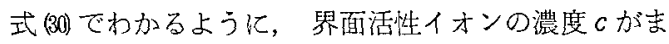
すと，その吸着のために $\psi_{1}$ が変化するが，同時に $\psi_{1}$ の絶対值は $\sqrt{c_{e} /\left(c+c_{e}\right)}$ の制合で低下する，煺って一 般に $\psi_{1}$ vs. $\log c$ 曲線は極大を示し，ceが大きいほど 極大は $c$ の高濃度側に移期する ${ }^{27}$. これは奏験において も腐々経験されるてとで, 結局浴液のイオン強度がます とその平方根㦈比例して二重層の愿さが低下すること の表わ机に外ならない，式 (32)では $k$ "にも火が效くの でこの效果はさらに著しい，従って， $\phi_{1} は$ Stern 層で の吸着量のみでなく拡敬二重層の愿さにも依存し，実験 を行なうに当ってこのことを十分理解しておく必要があ る、例えば支特笽を加えないときは理論的には $c_{e}=0$ で ある. 従って $c=0$ なら式 (30)，(31)で $\psi_{1}$ は不定となる が，実際には液中の $\mathrm{H}^{+}, \mathrm{OH}^{-}, \mathrm{CO}_{3}^{--}$, その他種々の不 純物イオンによってCeが与えられるからce は明確に規 定し難く， $\psi_{1}$ の值は頗る不安定で再現性に之しいだろ う.ての点は㭉外理解されていないので注意を促した次 第である.

この因難をさけるため支持塪を十分加えてイオン強度 を規定すると有利である．特に $c_{e} \gg c$ という条件では 式 (32) は次の形をとる,

$$
\psi_{1}=\psi_{1}^{*}+\frac{k k^{\prime} c}{1+k c}
$$

この上きは等電点 $c=c^{0}$ では $\psi_{1}=0$ だから，

$$
\begin{aligned}
& \left(\frac{d \psi_{1}}{d \log c}\right)_{c=c_{0}}=-2.303 \psi_{1} *\left(1+\frac{\psi_{1}^{*}}{k^{\prime \prime}}\right) \\
& \frac{1}{c^{0}}=-k\left(1+\frac{k^{\prime \prime}}{\psi_{1}^{*}}\right)
\end{aligned}
$$

すなわち $\psi_{1}$ vs. $\log c$ 曲線の等電点 $c^{0}$ とその点におけ る勾配から $k$ と $k$, 従って $\nu_{m}$ と $\Delta \bar{G}$ が計算できる. 式 (27)から $\psi_{1}=0$ では $\Delta \bar{G}=\Delta G$ だから，乙こにえられ た娄のは化学的吸着自由エネルギーを示すが，そのくわ しい解釈については電極の絶刘電位差の問題がからんで いるので面倒である20.28). 


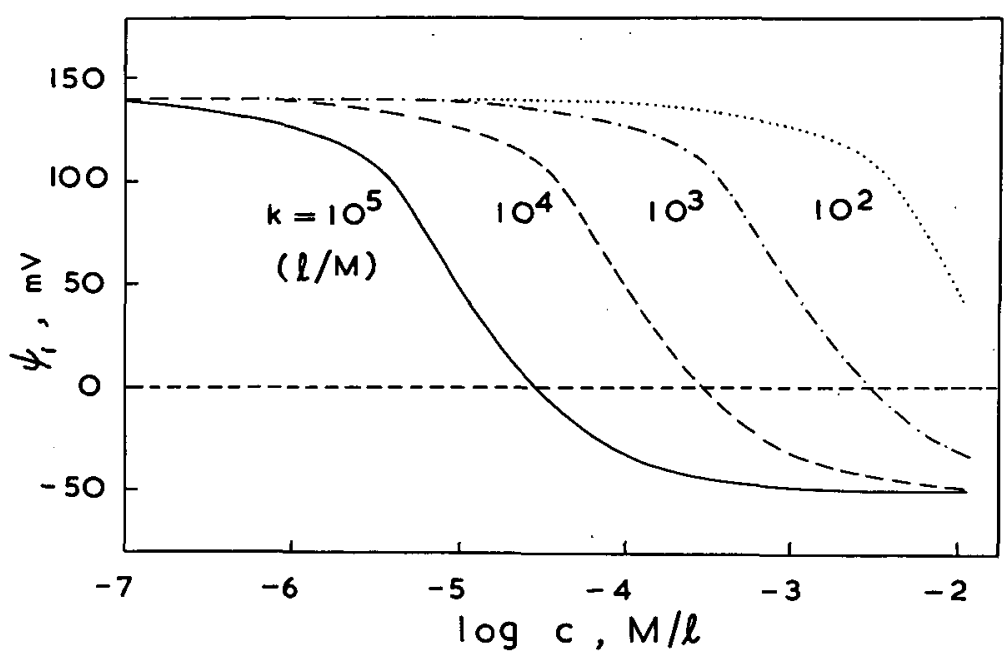

Fig. 2 Theoretical $\psi_{1}$ vs. $\log$ concentration curves. $\nu_{m}=1.94 \times 10^{13} \mathrm{~cm}^{-2}, \quad \kappa a=1.23, \quad a=10^{-6} \mathrm{~cm}$.

式(34) $亿 \varphi_{1}^{*}=140 \mathrm{mV}, \nu_{m}=1.94 \times 10^{13} \mathrm{~cm}^{-2}, \kappa a=1.23$, $a=100 \AA$ とおいたときのアニオン吸着 $(z=-1)$ におけ る $\psi_{1}$ vs. $\log c$ 理諭曲綵を Fig. 2 に示した。これら の数供は後に示す正の AgI ゾルの動電測定結果 (VI. 2 参照) と比較するために選九だるのである。

一般に $\nu_{m}$ が一定で $k$ が大きいと（吸着し易い上きほ ど)，曲線は形を一定に保ちながら全体がcの低い方に 移動する，一方， $\nu_{m}$ は勾配藷しく影響し， $\nu_{m}$ が大き いはご勾配の絶対值が大きい．これらは式(35)，(36) から 明らかであるう。

\section{N 粒子間相互作用}

\section{1 電気二重層の重胃}

(i) 平行平面：2つの平行な無限苧電平面が接近し てその電気二重層が重甾すると斥力が現われる，次に Langmuir ${ }^{33)}$ によるこの瓜打の計算法を略述しよう。

第1の平面を原点により，溶液内部に向って $x$ 軸を考 えよう，第 2 の平面の位置を $x=2 h$ とする (Fig. 3 ). $h \rightarrow \infty$ の上き $x \rightarrow \infty$ で $\psi \rightarrow 0$ であり，ての上き溶液内 の電解質濃度 (bulk 值) を $c_{e}(\mathrm{M} / \mathrm{l})$ とする。 ここに

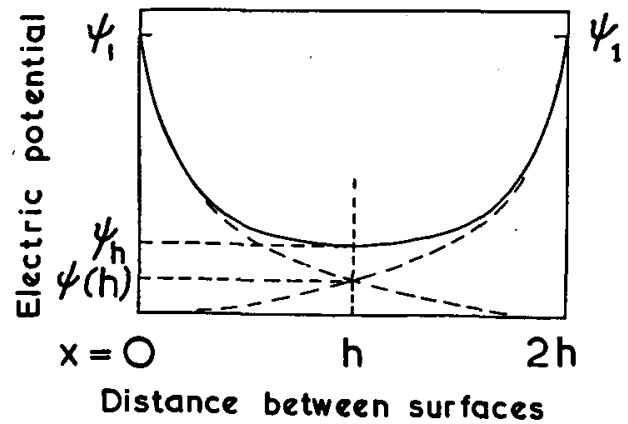

Fig. 3 The superposition of double layers. $z-z$ 洒電解質とする。任意の $h$ K つき面 $x=h$ （両平面から等距離の 面）での対イオンと同符号イオンの 濃度は夫ヶ Boltzmann 分布によ り次式で与えられる，

$$
c_{e} \exp \left(z \boldsymbol{e} \psi_{h} / \boldsymbol{k} T\right)
$$

および

$$
c_{e} \exp \left(-z \boldsymbol{e} \psi_{h} / \boldsymbol{k} T\right) \cdot \psi
$$

ここに $\psi_{h}$ はこの面での電位で， 单一の電気二重層内 $の=h$ の位 置での雷位 $\psi(h)$ と次の関係をむつ (電位の重曽性),

$$
\psi_{h}=2 \psi(h)
$$

徉って二重層の重曽にもとつくく面 $x=h$ でのイオン濃度の全增分は

$$
\begin{aligned}
\Delta c_{e} & =c_{e}\left\{\exp \left(z \boldsymbol{e} \psi_{h} / \boldsymbol{k} T\right)+\exp \left(-z \boldsymbol{e} \psi_{h} / \boldsymbol{k} T\right)-2\right\} \\
& =2 c_{e}\left\{\cosh \left(z \boldsymbol{e} \psi_{h} / \boldsymbol{k} T\right)-1\right\}
\end{aligned}
$$

てれに対応する滲透压

$$
P=\boldsymbol{N} \boldsymbol{k T} \cdot \Delta c_{e}
$$

が禹平面間の単位面積あたりの圧力に外ならない：こ のとき二重層を1つ形成するための自由エネルギー $\left(\mathrm{cm}^{-2}\right)$ を $F(2 h)$ とすると,

$$
F(2 h)-F(\infty)=-\int_{\infty}^{n} P d x
$$

両平面間の厉力のポテンシャル・エネルギー $V_{R}(2 h)$ は $2 つ の$ 電気二重層 $\left(1 \mathrm{~cm}^{2}\right)$ を造るための自由エネルギー 変化に等しいから,

$$
V_{R}(2 h)=-2 \int_{\infty}^{h} P d x
$$

(37)，(38)，(39)，(40)より $V_{R}(2 h)$ が計算できる. とくに相 互作用の弱い $\kappa x \gg 1$ のときには(3) に式 (23)を代入し, さらに Debye-Hückel 近似 $\left|z e \psi_{h}\right| \ll \boldsymbol{k} T$ が成立する として $\cosh y \cong 1+y$ とおくと次式加導加れる，

$$
V_{R}(2 h)=\left(64 \boldsymbol{N} \boldsymbol{k} T c_{e} / 1000 \kappa\right) \boldsymbol{\gamma}^{2} \exp (-2 \kappa h)
$$

こ扎が距離 $2 h$ の 2 つの平行平面間の斥力のポテンシャ ル・エネルギー $\left(\mathrm{cm}^{-2}\right)$ の近似式である。

(ii) 球形粒子 ( $\kappa a$ が大きいとき)：2つの球形稙子 が近づくときの $V_{R}$ の計算はそう簡単ではない ${ }^{19,34,35,36) . ~}$ しかし電解質濃度が高く粒子が大きいとき $(\kappa a \gg 1) に$ は，次のようにして质力を求めるてとができる ${ }^{18)}$.

中心が $\mathrm{O}_{1}, \mathrm{O}_{2}$ の 2 つの球間の斥力のポテンシャル. エネルギーは無限小の平行円環 $A_{1}, A_{2}$ 闃の斥力のポテ ンシャル・エネルギー

$$
2 \pi y \cdot V_{\boldsymbol{R}}(2 h) \cdot d y
$$

を全表面について積分してえられる（Fig.4）。すなれ 


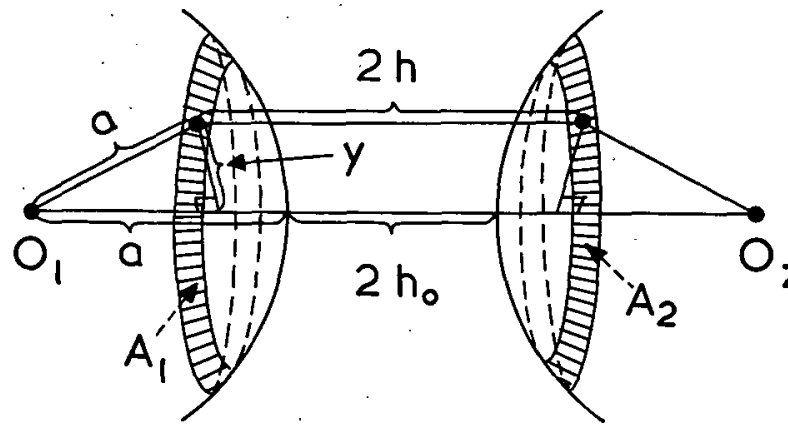

Fig. 4 Approaching spherical surfaces.

ち全斥力のポテンシャル・エネルギー $V_{R}\left(2 h_{0}\right)$ は両球 面の最短距離 $2 h_{0}$ の関数で，次式で与えられる.

$$
V_{R}\left(2 h_{0}\right)=\int_{0}^{\infty} 2 \pi \mathrm{y} \cdot V_{R}(2 h) d y
$$

$V_{R}(2 h)$ には式 (41) 在代入し，幾何学上り

$$
h-h_{0}=a-\sqrt{a^{2}-y^{2}}
$$

從って

$$
y \cdot d y=\sqrt{a^{2}-y^{2}} \cdot d h
$$

両球面で $a \gg y$ の部分怔死倒的に効くから

$$
y \cdot d y \simeq a d h
$$

と枕くと，式(42)より

$$
\begin{aligned}
V_{R}\left(2 h_{0}\right) & =\frac{2 \pi \cdot 64 \cdot c_{e} \cdot N \boldsymbol{k} T \gamma^{2} a}{\kappa \cdot 1000} \int_{h_{0}}^{\infty} \exp (-2 \kappa h) d h \\
& =\left(\frac{64 \pi \boldsymbol{N} \boldsymbol{k} T \gamma^{2} a c_{e}}{\kappa^{2} \cdot 1000}\right) \exp \left(-2 \kappa h_{0}\right)
\end{aligned}
$$

$\kappa^{2}$ に(18)を代入すると，

$$
V_{R}(u)=\left(\frac{8 \boldsymbol{k}^{2} T^{2} \gamma^{2} \varepsilon a}{z^{2} e^{2}}\right) \exp (-\kappa a u)
$$

$25^{\circ} \mathrm{C}$ では

$$
V_{R}(u)=4.62 \times 10^{-6}\left(a \gamma^{2} / z^{2}\right) \exp (-\kappa a u)
$$

こに

$$
u \equiv 2 h_{0} / a
$$

は精子間距漓隹を表わす無次元のパラメターである。

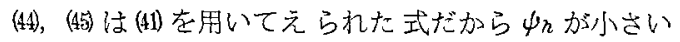
ときに成立し，大抵の目的にたいしてれで十分よい近儲

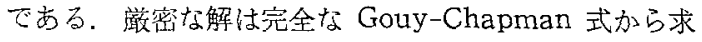
めた $V_{\boldsymbol{R}}(2 h)$ を(42)に代入して図式棈分を行なって求め られる ${ }^{18)}$.

(iii) 球玥䊀子（火aが小さいとき）：2つの二重層よ り成る系の自由エネルギーF你式で与えられる，

$$
F=-(1 / 2) Q_{1} \psi_{1}
$$

ここに $Q_{1}$ は 1 つの球表面の全電荷である.（くわしく 云うと表画電荷とStern 層電荷の代数和で，溶液内部 加ら球面を見たときの Stern 面の net の電荷である.) 2 つの球面が $\infty$ から距離 $2 h_{0}$ まで近つくときの $\Delta F$ が
斥力のポテンシャル・エネルギー $V_{R}(u)$ に等しい 加

$$
V_{R}(u)=\left\{Q_{1}(\infty)-Q_{1}\left(2 h_{0}\right)\right\} \psi_{1}
$$

又は

$$
V_{R}(u)=\left\{\psi_{1}\left(2 h_{0}\right)-\psi_{1}(\infty)\right\} Q_{1}
$$

(48)は表面が近づくとき電位が一定の場合, 又(49)は 電荷が一定に保たれる場合の式である。

(48)，(49) の計算には $\psi_{1}$ と $Q_{1}$ の関係が必要である. Poisson-Boltzmann 式に Debye-Hückel 近似を 適用すると（III·3 参照)，

$$
\nabla^{2} \psi=\kappa^{2} \psi
$$

一方静電気学の GauB の定理より

$$
Q_{1}=-\int \frac{\varepsilon}{4 \pi}\left(\frac{\partial \psi}{\partial r_{1}}\right)_{\begin{array}{c}
\theta_{1}=- \text { 定 } \\
r_{1}=a
\end{array}} d \omega_{1}
$$

ここに $\omega_{1}$ は第 1 の粒子の表面菜片の立体角である(Fig. 5). (50) と(51)から $\psi_{1}$ と $Q_{1}$ の関係がえられ，乙れを(48)， (49) に代入して次の関係式がえられた ${ }^{18)}$.

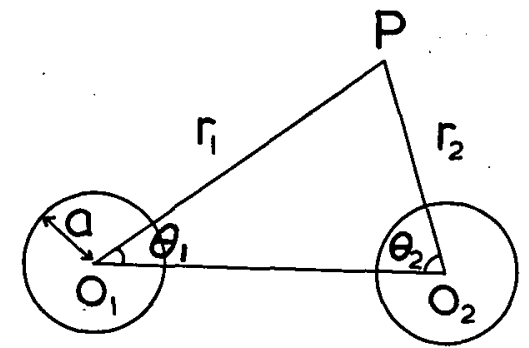

Fig. 5 Approaching spherical particles.

$$
V_{R}(u)=\frac{\beta \psi_{1}^{2} \varepsilon a \exp (-\kappa a u)}{u+2}
$$

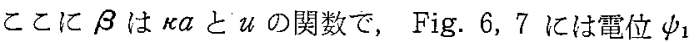
一定, および電荷 $Q_{1}$ 一定， のときの $\beta$ vs. $u$ 曲楾を кa老 parameter によって示した.

2 つの粘子が近づくとき $\psi_{1}$ が一定か $Q_{1}$ が一定かは

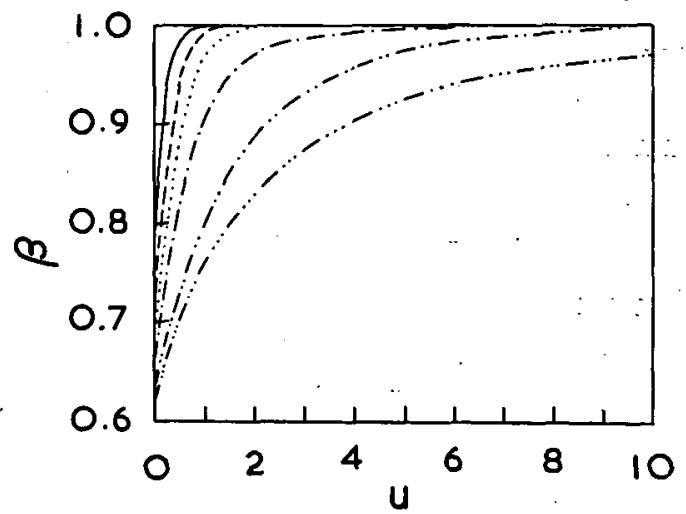

Fig. 6 s vs. $u$ curves for constant Stern potentials. $\begin{aligned} \kappa a ;-. . . & 0.1 ;-\cdots-0.3 ;--1.0 \\ \ldots . . & 2.0 ;---3.0 ;-5.0 .\end{aligned}$ 


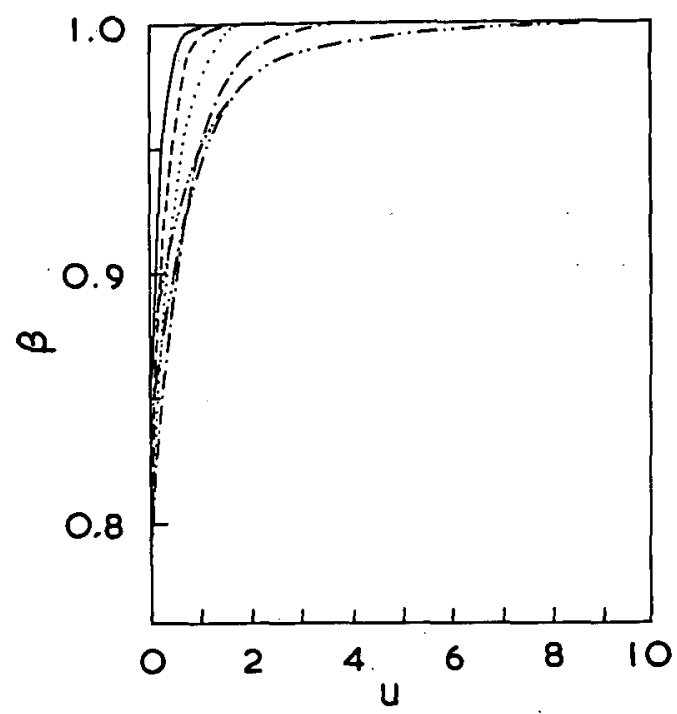

Fig. $7 \boldsymbol{\beta}$ vs. $u$ curves for constant surface charges.

$$
\begin{aligned}
& \kappa a ; \cdots-0.1 ; \cdots-0.3 ;-\cdots 1.0 \text {; } \\
& \text { …. } 2.0 ;---3.0 ;-5.0 \text {. }
\end{aligned}
$$

議諭のあるところだが，図から $\beta$ は 0.6 上 1.0 の間で 节って，籗密な理論を必要としないときは $\beta=1$ とと ると計算が非常に簡単となり，又大抵の目的にたいして はこれで十分間に合う。

式 (52) は Debye-Hückel 近似が成立しかつ火aが小さ

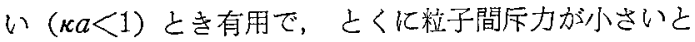
きには $\kappa a<10$ まで用いるととができる，一方， $\kappa \mathrm{a} \gg 1$ では (44) が(45)によって任意の $\psi_{1}$ につき $V_{R}(u)$ を求め ることができる，ただ， ときの計算は簡単には行なえない192.

\section{2 van der Waals 引力}

London の理諭 ${ }^{37}$ 亿よると距離 $r$ の 2 つの原子間の van der Waals 引力は短距離力で，そのポテンシャ ル・エネルギー $V_{A}(r)$ は次式で与 えられる，

$$
V_{A}(r)=-\lambda / r^{6}
$$

ここに比例定数入は次式で計算でき $\zeta^{382}$,

$$
\lambda=11.25 \times 10^{-24} \sqrt{s \alpha^{3}}
$$

ここにsは原子の最外款電子数, $\alpha$ は分極率である，水分子相互間で は $s=8, \alpha=1.43 \times 10^{-24}$ として ${ }^{18)}$

$$
\lambda=54 \times 10^{-60}
$$

接近するコロイド粒子間の引力の ポテンシャル・エネルギーを求める には，第 1 と第 2 の粒子に属する原
子の対のすべてについて (53) の $V_{A}(r)$ の和芷誩算すれ ばよい，各粒子には非常に多数の原子がふくまれている から，全引力は(53)よりずっと遠距離に及ぶことがわか $3^{39,403}$. Hamaker ${ }^{41)}$ 亿よると, 厚さ $d$ で表面間の距離 が $2 h$ のつの無限板の間の引力のポテンシャル・エネ ルギー $V_{\boldsymbol{A}}(2 h)$ は

$$
V_{A}(2 h)=-\frac{A}{48 \pi}\left\{\frac{1}{h^{2}}+\frac{1}{(h+d)^{2}}-\frac{2}{(h+d / 2)}\right\}
$$

Łくに

$$
\begin{aligned}
& h \ll d \text { では } V_{\boldsymbol{A}}(2 h)=-A / 48 \pi h^{2} \\
& h \gg d \text { では } V_{A}(2 h)=-A d^{2} / 32 \pi h^{4}
\end{aligned}
$$

一方, 球の間の引力については

$$
V_{A}(u)=-\frac{A}{6}\left\{\frac{2}{u(u+4)}+\frac{2}{(u+2)^{2}}+\ln \frac{u(u+4)}{(u+2)^{2}}\right\}
$$

とくに

$u \ll 1$ では

$$
V_{A}(u)=-A / 12 u
$$

ここに

$$
A=\pi^{2} Z^{2} \lambda
$$

$Z$ は $1 \mathrm{~cm}^{3}$ あたりの原子数である，Aをvan der Waals 定数之上ぶ. 真空中の球については (61)でよいが, たとえば水中の粒子では

$$
A=A_{11}+A_{22}-2 A_{12}
$$

となり， $A_{11}, A_{22} ， A_{12}$ はそれぞれ粘子-粒子間，水一水 間，粒子一水間についての (61)の形の定数である、Aは常 に正で $V_{A}(u)$ は引力を表方す.

水について (55)，(61) により $A_{22}$ を計算するる $A_{22}=0.6$

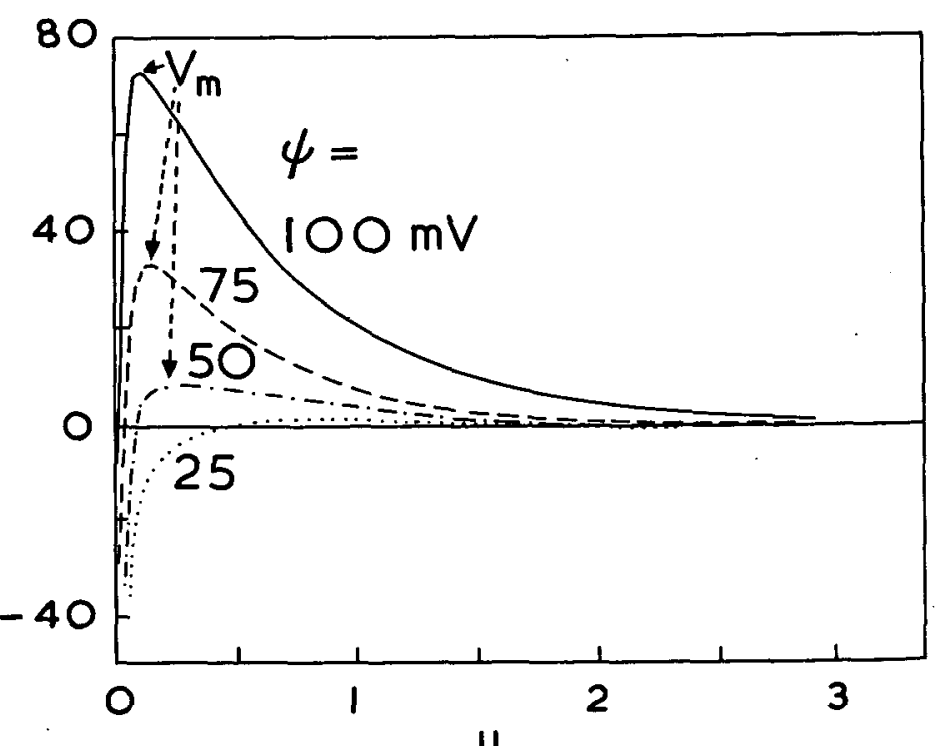

Fig. 8 Theoretical $V / k T$ vs. $a$ curves. $\kappa a=1.23, a=10^{-6} \mathrm{~cm}$. 
$\times 10^{-12} \mathrm{erg}$ となるが,一般に $A$ は $10^{-12} \mathrm{erg}$ 附近の值 をとるのがふつうである。

3 全ポテンシャル曲線

かくて $V_{R}(u) £ V_{A}(u)$, 又は $V_{R}(2 h)$ ¿ $V_{A}(2 h)$ が計算できたから，相互作用の全ポテンシャル・エネル ギー $V(u)$ 又は $V(2 h)$ は単に両者の代数和で与えられ る.たとえば $\kappa a=1.23, a=100 \AA, A=10^{-12} \mathrm{erg}, \beta=1$ と执いて(52) と(60) 加ら得た式

$$
V(u)=\frac{\varepsilon_{a} \psi_{1}^{2}}{u+2} \exp (-\kappa a u)-\frac{A}{12 u}
$$

を用いて計算した $V(u)$ vs. $u$ 理論曲線老 Fig. 8 に示 す. $\phi_{1}$ が大きいと極大 $V_{m}$ が見られ，てれが 2 粒子の 衝突に対する potential barrier となる711， $\psi_{1}$ が低い こ $V_{m}$ は小さくなり， $\psi_{m}=25 \mathrm{mV}$ では $V_{m} \cong 0$ となっ て自由拡散 (急速凝集) が起る (II 参照). 定性的仁云 うと $V_{m} \cong 15 k T$ で衙笑回数は $1 / 10^{5}$ に，又 $25 k T$ で $1 / 10^{9}$ 程度に低下してのときにはコロイドは十分安定で あると云える.

尚，条件によっては極大の外側に浅い第 2 の極小が現 われる.ふつうその深さは非常に浅いので凝集の議論に おいては無視してよいが, thixotropy, gelationなど の粘弾性の問題, その他色々のコロイドの興味ある現象 にこの secondary minimum が与っていると云われ $ろ^{18,80,81)}$.

\section{$\mathrm{V}$ 䌅 慢 凝 集}

1 Fuchs の関係式

粒子間力を $\boldsymbol{F}$ ，粒子が運動するときのまさつ抵抗を $f^{\prime}$ とする亡, 式(1)は次の形化搪張される，

$$
\frac{\partial N(r, t)}{\partial t}=\frac{1}{r^{2}} \frac{\partial}{\partial r}\left[D^{\prime} r^{2} \frac{\partial N(r, t)}{\partial r}-r^{2} \frac{F}{f^{\prime}} N(r, t)\right]
$$

粒子闒ポテンシャル・エネルギーを $V(r)$ とすると

$$
\boldsymbol{F}=-d V(r) / d r
$$

また(2)，(11)より

$$
f^{\prime}=3 \pi \eta a=k T / D^{\prime}
$$

従って(63)より

$$
\frac{\partial N(r, t)}{\partial t}=\frac{D^{\prime}}{r^{2}} \frac{\partial}{\partial r}\left[r^{2}\left\{\frac{\partial N(r, t)}{\partial r}+\frac{N(r, t)}{k T} \frac{d V(r)}{d r}\right\}\right]
$$

これが粒子間力の働く場合の一般拡散偏微分力程式で ある42)。この式はまだ完全には解かれていないが43，

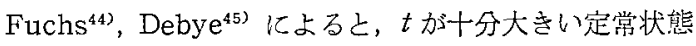
での flux $J$ は次式で与えられる

$$
J=\frac{8 \pi D N}{\int_{2 a}^{\infty} \frac{1}{r^{2}} \exp \left\{\frac{V(r)}{k T}\right\} d r}
$$

とくに $V(r)=0$ とおくとII の急速疑集 (自由拡散) で の flux $J_{r}$ になる,

$$
J_{r}=16 \pi a D N
$$

$J$ は半径 $2 a$ の球面に単位時間に衝突する粒子数だか ら， $J_{r} / J$ 忙急速凝集乙緩慢凝集 (slow coagulation) の速度比であり，乙れをそのコロイドの安定度（stability factor) $W$ 亡定義する ${ }^{18,30)}$.すなわち, 式(46)在用 Wて, (65) と(8)よb

$$
\begin{aligned}
W & =2 a \int_{2 a}^{\infty}\left(1 / r^{2}\right) \exp \{V(r) / \boldsymbol{k} T\} d r \\
& =2 \int_{0}^{\infty} \exp \{V(u) / k T\} d u /(u+2)^{2}
\end{aligned}
$$

$V(u)=0$ なら $W=1$ (急速凝集)， $V_{m}>0$ なら (Fig. 8 参照) $W>1$ (綬慢凝集) である. 式(9)と比皎して

$$
-d N / d t=k_{r} N^{2} / W
$$

すなわち $W>1$ のとき凝集速度定数は急速凝集の塲合 の定数 $k_{r}$ の 1/W に低下している.

\section{2 緩慢凝集の分類}

簡単のために平行平面を考えると，Fig. 3 加ら明ら かなように，何らかの方法で $\phi_{h}$ を低下させると二重癏 斥力が弱くなり，従って凝集速度がます。一般に搪散二 重層の性質は $\psi_{1}$ と $1 / \kappa$ で決定さ机るから，結局その 何れかを低下させれば $V_{R}(2 h)$ ，或いは $V_{R}(u)$ が小さ くなり，従ってWが低下する。

(i) 非特異的凝集 (Schulze-Hardy 凝集)：電解質 を加えて1/火を低下させたときの凝集である（Fig.9

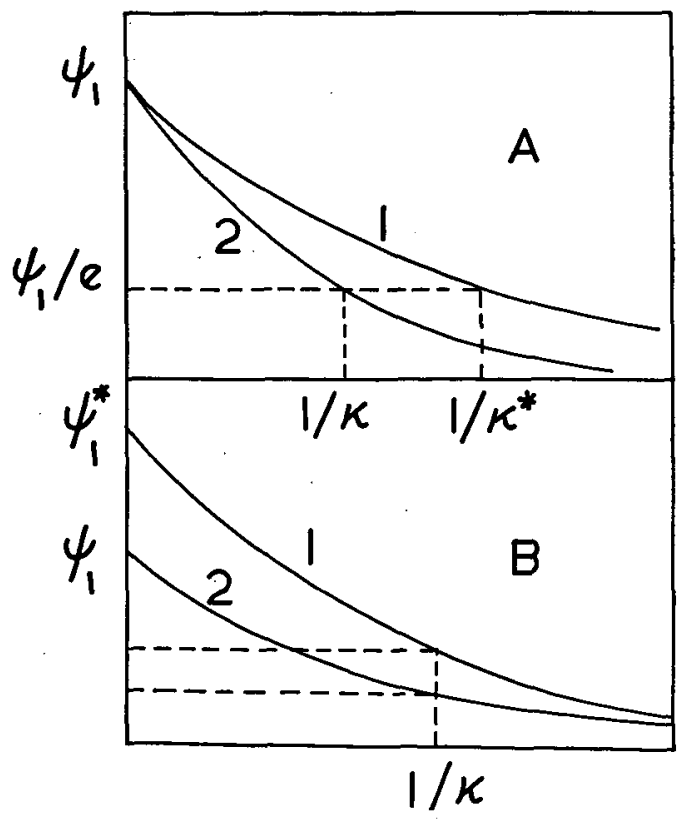

Fig. 9 Changes in the potential distribution in the electrical double layer. A, the double layer com. pression, and B, the Stern potential suppression. 
A)、すなわ方式(18)より， $\boldsymbol{z}$ や $c_{e}$ が大きいほぼ 1/火は 小さい，乙の場合ふつう $\psi_{1}$ はほとんじ変化しない（次 節参照)。加る機構の凝蒜ではコロイド粒子の帯電 と反対符号のイオンの原子価之濃度が支配的役割を演 じ，その原子価が大きいほど凝集濃度が低く，いわ河る Schulze-Hardy の法則が成立する，そして加えた電解 質のイホン成分の特筫性の效果は見られない.

(ii) 特買的凝集：乙れは加えた電解質の成分イオン の特異性がコロイド安定度 $W$ に効く埸合で，乙のとき $\psi_{1}$ の変化が見られる（Fig. 9 B)。 ふつう加える凝集 剂は非常に低濃度で效くから，1/ルがほとんど変化しな いのが一般である。

\section{3 非特異的凝集}

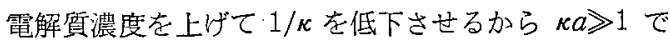
の近似式 (45) から導いた式を用いることができる，すな わ⿱

$$
V(u)=\frac{4.62 \times 10^{-6} a \gamma^{2}}{z^{2}} \exp (-\kappa a u)-\frac{A}{12 u}
$$

(i) 凝集濃度 : 凝集濃度 (凝結価) $c_{e}^{+}$とは急速凝

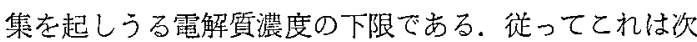
の条件を満足する $c_{e}$ 值である ${ }^{18)}$,

$$
d V(u) / d u=0, \quad V(u)=0
$$

式(68)より

$$
\begin{aligned}
d V(v) / d u & =\frac{A}{12 u^{2}} \\
& -\frac{4.62 \times 10^{-6} a \gamma^{2} \kappa a}{z^{2}} \exp (-\kappa a u)=0
\end{aligned}
$$

これを $V(u)=0$ に代入して

$$
V(u)=\frac{A}{12 u}\left(\frac{1}{\kappa a u}-1\right)=0 \quad \therefore \kappa a u=1
$$

従って

$$
V(u)=\frac{4.62 \times 10^{-6} a \gamma^{2}}{z^{2}} \exp (-1)-\frac{A \kappa a}{12}=0
$$

すなわち，(18）を代入して

$$
\frac{1.70 \times 10^{-6} a \gamma^{2}}{z^{2}}=\frac{A a}{12} \sqrt{\frac{8 \pi e^{2} \boldsymbol{N}}{1000 \varepsilon k T}} \sqrt{c e^{+} z^{2}}
$$

あるいは

$$
c_{e}^{+}=B \cdot \gamma^{4} / z^{6}
$$

ここに $B$ は van der Waals 定数 $A$ と粒子半径 $a$ を ふくむ定数である.

式(21)より $\left|\psi_{1}\right|$ が小さいときは $\gamma \cong z e \psi_{1} / 4 \boldsymbol{k} T$ であり， $\left|\psi_{1}\right|$ が大きいときは $\gamma \cong 1$ である。従って

$\left|\psi_{1}\right|$ が小さいとき

$$
c_{e}{ }^{+}=B^{\prime} \psi_{1}{ }^{4} / z^{2}
$$

- $\left|\psi_{1}\right|$ が大きいとき

$$
c e^{+}=B^{\prime \prime} / z^{6}
$$

ここに $B^{\prime}$ と $B^{\prime \prime}$ は $A$ と $a$ をふむ定数である。(70)か らわかるように，与えられたゾル $\left(A ， a ， \phi_{1}\right.$ が一定)で は $c e^{+}$は $z$ のの関数で， $z$ が大きいほよ゙ $c e^{+}$は小さ い. 特に $\left|\psi_{1}\right|$ が小さいときは，(71)より， $\psi_{1}$ が等しいッ゙ ルについてのみ $c_{e}^{+}$に及に゙す $z$ の効果が比較できるが， ふつう Schulze-Hardy 凝集では電解質添加による $\psi_{1}$ の変化は小さいので， $c e^{+}$は $z^{2}$ に逆比例すると考えて

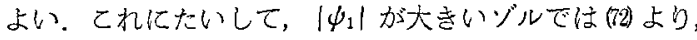
$c e^{+}$は $\psi_{1}$ に無関係で $z^{6}$ 亿逆比例する，汃くて(71)，(72)は 経験的に知られていた Schulze-Hardy の法則 ${ }^{46-49,72,73)}$ を定量化したものであり，さらにとの法則が柽子間相互 作用にもとづく理論的根拠をむっているととを示してい る.

上の議諭は対称型 $z-z$ 価電解質の理論を 用いて論じ ている. 非対称型の電解質では， $\psi_{1}$ と異符号のイオン 成分在 $\boldsymbol{z}$ 価，同符号のイオン成分を $z^{\prime}$ 価（符号はふく まない）とするとき，両種イオンの分布を示す項はそれ ぞれ $\exp \left(\boldsymbol{z} \boldsymbol{e} \psi_{1} / \boldsymbol{k} T\right), \exp \left(-\boldsymbol{z}^{\prime} \boldsymbol{e} \boldsymbol{\psi}_{1} / \boldsymbol{k} T\right)$ 亿比例する. 一般に後者は前者隹対して十分型視できるのがふつう で，結局 $\psi_{1}$ 之同符号のイオン成分は拡散二重層の性質 にほとんざ影響しない，従って (71)，(72)において $z$ は $\psi_{1}$ と反対符号のイオン成分の原子価上考えてよいわけであ $\zeta^{18)}$.

(ii) 緩慢凝集での安定度 : Reerink とOverbeek ${ }^{50}$ は(68)を(66) 亿代入し，被積分関数の Taylor 展開によ る近似計算を行なって次の関係を導いた，

$$
\log W=-\frac{2.15 \times 10^{7} a \gamma^{2}}{z^{2}} \log c_{\theta}+K
$$

とこに

$$
\begin{aligned}
K & =\left(\frac{3}{2}-\frac{A}{12 u_{m} \boldsymbol{k} T}\right) \log u_{m}+\frac{1}{2} \log \frac{96 \pi \boldsymbol{k} T}{A} \\
& -\frac{A}{24 u_{m} \boldsymbol{k} T} \log \frac{8 \pi \boldsymbol{N} z^{2} \boldsymbol{e}^{2} a^{2} \cdot 10^{-6}}{\varepsilon \boldsymbol{k} T} \\
& -\log \left(2-\kappa a u_{m}\right)^{1 / 2}\left(u_{m}+2\right)^{2}
\end{aligned}
$$

$u_{m}$ は $V(u) v s . u$ 曲線の極大 $V_{m}$ を与える $u$ 值で, 次 式で与えられる,

$$
u_{m}=\frac{1}{\kappa a}=\frac{A \boldsymbol{e} z^{2}}{5.58 \times 10^{-5} a \gamma^{2}}
$$

式(73)でわかるように $\log W$ vs. $\log c_{e}$ 㤋負の勾配を 屯つ直線であり，その勾配から(74)によって van der Waals 定数 $A$ の值を計算することができる。

\section{4 特異的凝第}

加えた電解質イオンの特買性が凝集比效く場合があ る。例えば上の Schulze-Hardy 凝集において 僅かに 対イオンの性質による差異が見られるし，さらにときに は完全に Schulze-Hardy の法則からはずれるような 凝集現象委多く見られる。

(i) Hofmeister 列 : Schulze-Hardy の法則をく わしく調べると，同じ符号と原子価のイオンの凝集濃度 
が互に少しずつちがっている．この イオンの效果を凝集能力の大きいす のから順にならべると多くの場合次 の列がえられる1

1 価カチオンでは,

$\mathrm{Cs}^{+}>\mathrm{Rb}^{+}>\mathrm{NH}_{4}^{+}>\mathrm{K}^{+}>$ $\mathrm{Na}^{+}>\mathrm{Li}^{+}$

1 価アニオンでは, $\mathrm{F}^{-}>\mathrm{IO}_{3}^{-}>\mathrm{H}_{2} \mathrm{PO}_{4}^{-}>\mathrm{BrO}_{3}^{-}>$ $\mathrm{Cl}^{-}>\mathrm{ClO}_{3}^{-}>\mathrm{Br}^{-}>\mathrm{NO}_{3}^{-}>$ $\mathrm{ClO}_{4}^{-}>\mathrm{I}^{-}>\mathrm{CNS}^{-}$

これはゲルの膨澗，親水性コロイド の壏析，電解質溶液の赤外スペクト ル，粘度，水和熱，イオン化電位な どであ見られるいわ礼る Hofmeister 列である゙,82). これはイオン半 径に関係していることが加ってい る. その凝集效果の差もやはり，こ れらのイオンが Stern 㳟に吸着し て $\left|\psi_{1}\right|$ を低下させる度合の差浜よ るものだろう。

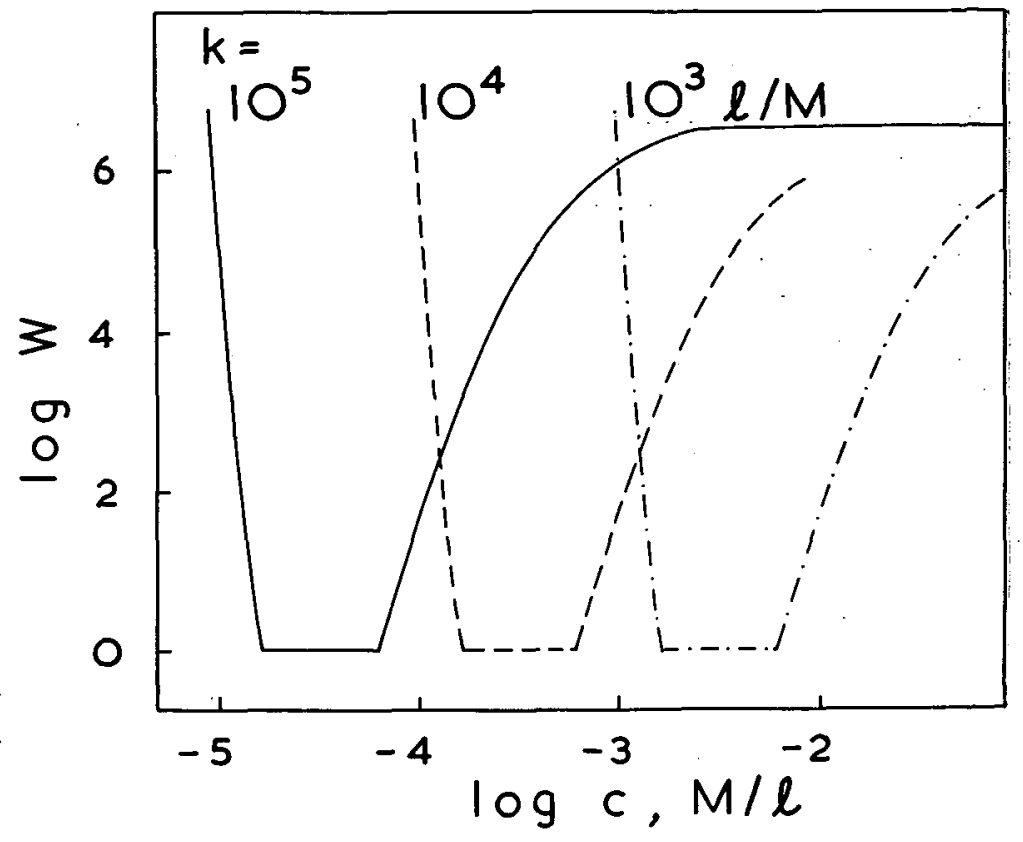

Fig. 10 Theoretical log stability vs. $\log$ surface active agent concentration curves.

（ii）電位決定イオン：電気二重層の電位分布は表面 の電位 $\psi_{0}$ に依存すること注明らかである. 従って電位 決定イオンの濃度は凝集沈おいて基本的な役割を演じ る.たとえば $\mathrm{pAg} 8$ の負の $\mathrm{AgI}$ ゾルに $\mathrm{AgNO}_{3}$ を加

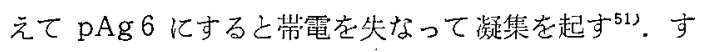
なわち $\left|\psi_{0}\right|$ と共化 $\left|\psi_{1}\right|$ が低下ずるからである. 同じ 1 価イオンでも $\mathrm{Ag}^{+} や \mathrm{I}^{-}$の電位決定イオン以外の無関 係イオン (indifferent ion) なら，との数百万倍の濃 度ではじめて凝集が起る。たとえば $\mathrm{KNO}_{3}$ の凝集濃度 注約 $150 \mathrm{mM} / 1$ である. かくて，疎液性コロイドの安定 性は電位決定イオン榐度に極めて鋭敏である。

(iii) 吸着凝集: 吸着凝集では凝集剂として加える界 面活泩イオンの濃度 $c$ 注ふつう非常に小さい. 従ってコ ロイドのイオン強度はほとんど変化せず，1/火は十分大 きくて $V_{R}(u)$ に式(52)を用いることができる。簡単の ために $\boldsymbol{\beta}=1$ とおくと

$$
V(u)=\frac{\varepsilon a \psi_{1}^{2}}{u+2} \exp (-\kappa a u)-\frac{A}{12 u}
$$

(55)を(66)代代入してWを数值計算によって求めることが できる ${ }^{302}$. しかし， explicit な表現をうるため Taylor 展開による近似を用いると ${ }^{29,309}$,

$$
\begin{aligned}
\ln W & =\frac{A}{24 \boldsymbol{k} T}\left(\frac{L^{2} \psi_{1}{ }^{2}}{1+\kappa a}-2 L \psi_{1}\right) \\
& -\frac{3}{2} \ln \psi_{1}-\frac{3}{2} \ln L+M
\end{aligned}
$$

ここに

昭和39年 4 月

$$
\begin{aligned}
& L=\{12 \varepsilon a(1+2 \kappa a) / A\}^{1 / 2} \\
& M=-\frac{1}{2} \ln \frac{24 \pi \boldsymbol{k} T}{A}+\frac{A}{24 \boldsymbol{k} T}
\end{aligned}
$$

これが $\log W$ vs. $\psi_{1}$ の理論式である. $\log W$ とcの 関係を求好るには (76) 亿式 (34)を代入して

$$
\begin{aligned}
\ln W & =\frac{A L^{2} \psi_{1}{ }^{*}}{24 \boldsymbol{k} T(1+2 \kappa a)}(1+\xi)^{2}-\frac{A L \psi_{1}{ }^{*}}{12 \boldsymbol{k} T}(1+\xi) \\
& -\frac{3}{2} \ln (1+\xi)-\frac{3}{2} \ln \left(L \psi_{1}{ }^{*}\right)+M
\end{aligned}
$$

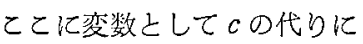

$$
\xi=\frac{\psi_{1}^{*} k k^{*} c}{1+k c}
$$

を用いた. Fig. 2 の計算に用いたのと同じ数值を(78)に 代入して (77)によって求奻た $\log W$ vs. $\log c$ 理論曲線 を Fig. 10 亿示した. ただし, 物理的若察より $\log W$ $\geqq 0$ であるから，急速凝集の領域ではすべて $W=1 に$ とった.

\section{5 一般凝集理論}

前節では $W$ が $\kappa a$ 又は $\psi_{1}$ にっって变化する場合を 別々に論じた。大抵の場合，乙の両機構は十分はなれた 濃度領域で起り，両者は実験的に分離することができ る.しかし，上きには両者が同じ濃度領域で起り，1/ の低下と $\left|\psi_{1}\right|$ の減少が同時化作用して $W$ を低下ざせ る.たとえば，Schulze-Hardy 凝集で僅かにイオンの 特異性が見られるのは，各イオンの特異吸着による $\psi_{1}$ の僅かな変化が，1/火の大きな変化に重畳するためと考 えら机る (4 参照). 
一般に $\dot{W}$ は $\psi_{1}$ 之 $a$ の関数であ るから， $\kappa a ， \psi_{1}, \log W$ を座標軸 にとればゾルの安定度は一つの曲 面 $\log W\left(\kappa a, \psi_{1}\right)$ で表現できる (Fig. 11) $)^{53,78)}$.

まず, Schulze-Hardy 凝集では 将はとんど一定で $\kappa a$ のが変化 する. 従って点Aで代表さ机る条件 のゾルの $\log W$ は, 電解質添加に よって面上を A から B まで下り， $\log W=0(W=1)$ の面に達して急 速凝集の領域に入り, 以後 $\mathrm{B} \rightarrow \mathrm{C} の$ 経路をたどる。乙れにたいして吸着 凝集では $\kappa a$ は注とんど変化せず $\psi_{1}$ のみが変化する，すなわち凝集剂濃 度がますにつれて $\log W$ はAから Dに下り， DからEまでは $\log W$ $=0$ の急速凝集が起り, さらに濃度 がますと $\mathrm{E} \rightarrow \mathrm{F}$ 経路を通って $\log$ $W$ は再び増大する．後に示す Fig. 21 はこの曲線の $\log W-\psi_{1}$ 面への投影汒ならない.

一般の凝集では，吸着凝集よ Schulze-Hardy 凝集 の何れが優勢かに従って， $\mathrm{A} \rightarrow \mathrm{H} \rightarrow \mathrm{I} \rightarrow \mathrm{J}$ と $\log W$ が 極小 $(\log W=0)$ をへて再び増大するか， $\mathrm{A} \rightarrow \mathrm{K} \rightarrow \mathrm{L}$ 亡 $\log W=0$ に達したまま増大しないか何れかの経路 をとる.

さて， $\psi_{1}$ と $\mathrm{a}$ は共に凝集剂濃度 $c$ の関数だから, 雨 者の間には関数関係が存在するはずである，従って結局 $\log W$ $\kappa a$ のみの関数と考えて上く， その依存性を 決定するのが㠜集剂の吸着力で，てれは式 (29)で与えら れる定数 $k$ によって特性つけられる. 理論的計算による 之 ${ }^{523}$ ，対イオン結合がないとき $(k \rightarrow 0)$ には，任意の ка に対して

$$
\frac{d \ln W}{d(\kappa a)} \rightarrow-\frac{\varepsilon a \psi_{1}^{* 2} u_{m} \exp \left(-\kappa^{*} a u_{m}\right)}{\boldsymbol{k} T\left(u_{m}+2\right)}
$$

ここに um は $V(u)$ vs. $u$ 曲線の極大 $V_{m}$ を与える $u$ 值である.*印は凝集剂濃度 $c=0$ のときの值を示す.

とくに条件 $\kappa^{*} a u_{m} \ll 1$ では

$$
\frac{d \ln W}{d(\kappa a)} \rightarrow-\frac{\varepsilon a \psi_{1} * 2 u_{m}}{\boldsymbol{k} T\left(u_{m}+2\right)}
$$

um は $\kappa a$ によって大して変化しないから (Fig. 8 参 照), 結局 $\ln W$ は $\mathrm{n}$ の一次減少関数亡なる。

\section{VI 動 電 測 定}

1 正の AgI ゾルの生成

たとえば $3 \times 10^{-3} \mathrm{M} / 1 \mathrm{AgNO}_{3} 200 \mathrm{ml}$ をビーカーに とり，激しくかく拌しながら徐々に $10^{-3} \mathrm{M} / 1 \mathrm{KI} 200 \mathrm{ml}$ を加える．とのとき生成する正に帯電した AgI ゾル

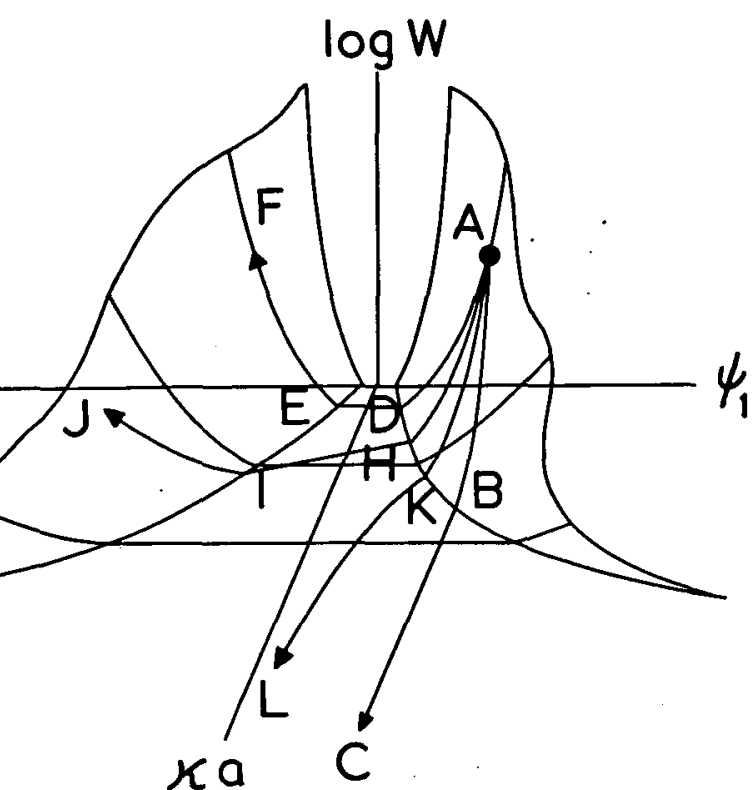

Fig. 11 The stability surface.

は $[\mathrm{AgI}]=5 \times 10^{-4} \mathrm{M} / \mathrm{l}, \mathrm{pAg} 3$ ，イオン強度 $1.5 \times 10^{-3}$ $\mathrm{M} / 1$ で, $0.5 \times 10^{-3} \mathrm{M} / 1 \oplus \mathrm{KNO}_{3}$ 加無関係塩としてふ くまれている，以後このゾルを正 AgI ゾル (pAg 3) とよぶことにしよう.ゾル調製直後には粒子の生長が見 られるから，暗室で約 3 時間空温に保って熟成を行なっ た後，乙れを動電現象や凝集の実験に用いる，AgI 礼 $\mathrm{AgBr}$ ほど光線に敏感ではないから上の実験操作は暗室 で行なう必要はないが，ゾルの保存は暗所が望ましい．

逆に過剩の $\mathrm{KI}$ 溶波に $\mathrm{AgNO}_{3}$ 溶液を加えると負の AgI ゾルができる ${ }^{83)}$. 加える液之加えられる液を逆に すると, 添加の途中で等電点 (pAg 6) を通り, このと き凝集が起る，従って均一なゾルができない，

\section{2 陙外顕微鏡電気泳動}

前章に導いた $W$ と $\psi_{1}$ の関係を実験的に証明するに は，まず $\psi_{1}$ の測定が必要である。しかしこれは頗る困 難な問題であり，これに代る実測可能な値としてふつう 界面動電位 ( $\zeta$ 電位) が用いられる 線方们に相刘運動が起るときすべりの起る面の電位（液

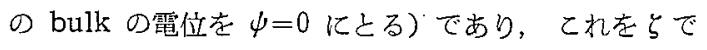
表わす. (Fig. 1 参照) このすべりの面の電気二重層内 における正確な位置は不明であるが ${ }^{74)}$ ，一応らは $\psi_{1} の$ 変化をほほ忠実に反映する量之考えられる.

われわれの実験では，丂の測定には限外顕微鏡電気泳

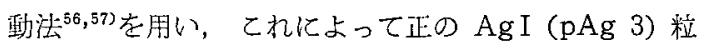
子の泳動速度 $U$ を測定した．このときセ儿壁と溶液の 界面江起る電気渗透流路 $U_{0}$ の補正が必要である. 内半 径 $R$ の円筒セルの軸から距離 $r$ のレベルでの粒子の見 加の易動度 $U^{\prime}$ は次式で与えられる。 


$$
U^{\prime}=U+U_{0}\left\{\left(2 r^{2} / R^{2}\right)-1\right\}
$$

従って $r=R / \sqrt{\overline{2}}$ のレベルでの易動度を測定して 真の $U$ 值を求めた。

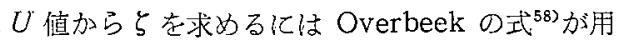
いられる。

$$
U=(\varepsilon \zeta / 6 \pi \eta) \mathrm{f}(\kappa a, \zeta)
$$

ここに $\mathrm{f}(\kappa a, \zeta)$ は relaxation 效果之 Henry 効 果 ${ }^{599}$ の補正を示す Overbeek の関数である。ふつ う粒子と液の電気伝導度の差による電場の局所的な ひずみにもとづく Henry 效果の補正のみが行なわ れているが，Fig. 12 に示すように $\kappa a$ が 10 の 領域では relaxation 効果が非常に效いてくる。わ れわ机の系では $\kappa a=1.23$ だからままにこの領 域である. 尚 Fig. 12 の曲線で $\boldsymbol{e} \zeta / \boldsymbol{k} T=0$ の曲線 は Henry 関数に外ならない。 $z$ が 1 以外の電解䆬 の場合の Overbeek 関数 $\mathrm{f}(\kappa a, \zeta)$ についてもく わしい計算が行なわれている ${ }^{58)}$. 式 (81) はらの㓌関数で 表現されている。そそてでUかららを求めるにはまず $\mathrm{f}(\kappa a, \zeta)=1$ の Smoluchowski 式によってらを計算

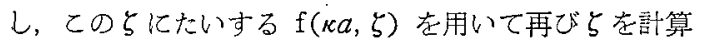
し，乙れを繰返して $\zeta$ の収れん値を求力た，実際には数 回の操作で十分である。

実験には水槽（䇪温）中につけた $R=1.185 \mathrm{~mm}$, 厚さ $0.160 \mathrm{~mm}$ の Pyrex ガラスの毛細管のセルを用い，倍 率 $15 \times 15$ の暗視野顕微镜によって $2.55 \mathrm{Vcm}^{-1}$ の電場 下での粒子のUを測定した，電場は交互に polarity 変え, 往復20回の平均の $U$ を求めた. 正の $\mathrm{AgI}, \mathrm{AgBr}$

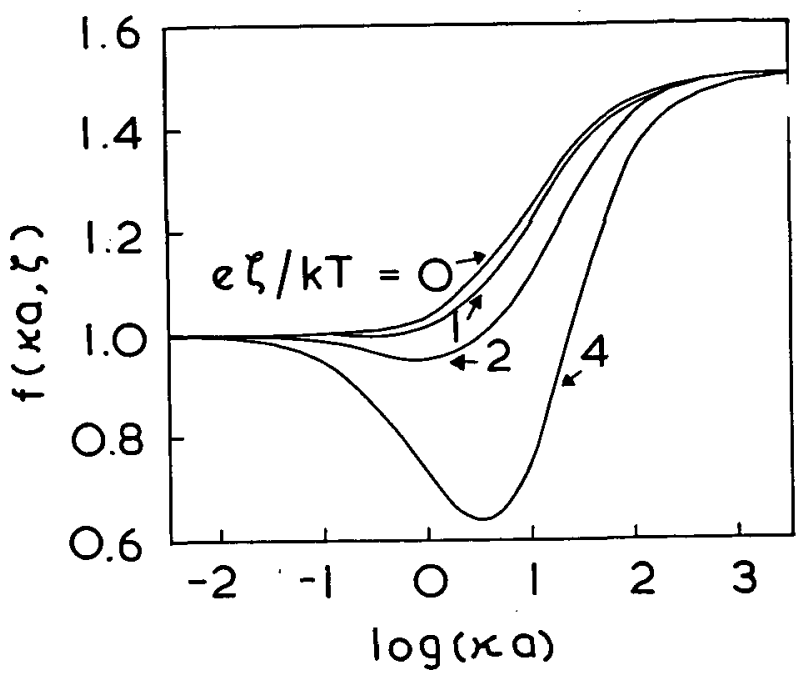

Fig. 12 The overbeek function for 1-1 electrolytes.

ゾルなどでは毛細管のガラス壁から溶け出した Silicate イオンがゾル精子の带電に影響を拉よばし，実験誤差の 原因となると之あにUの測定値の再現性を著しく低下 させる．との現像は純粋な $\mathrm{AgBr}$ 結晶生成における容 器の問題としてあ重要である ${ }^{75)}$. ふつう, ガラス容器を fluoride で処理して表面を不溶性の fluosilicate に転 换することによりこの問題を解決できる ${ }^{60)}$.

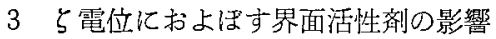

正の AgI ゾル (pAg 3) に種々のアニオン性界面活 性剂を加えた実験結果の数例を Fig. 13, 14 亿示す ${ }^{61}$. Fig. 13 は同じ head group $-\mathrm{SO}_{4}^{-}$をむつ SDeS

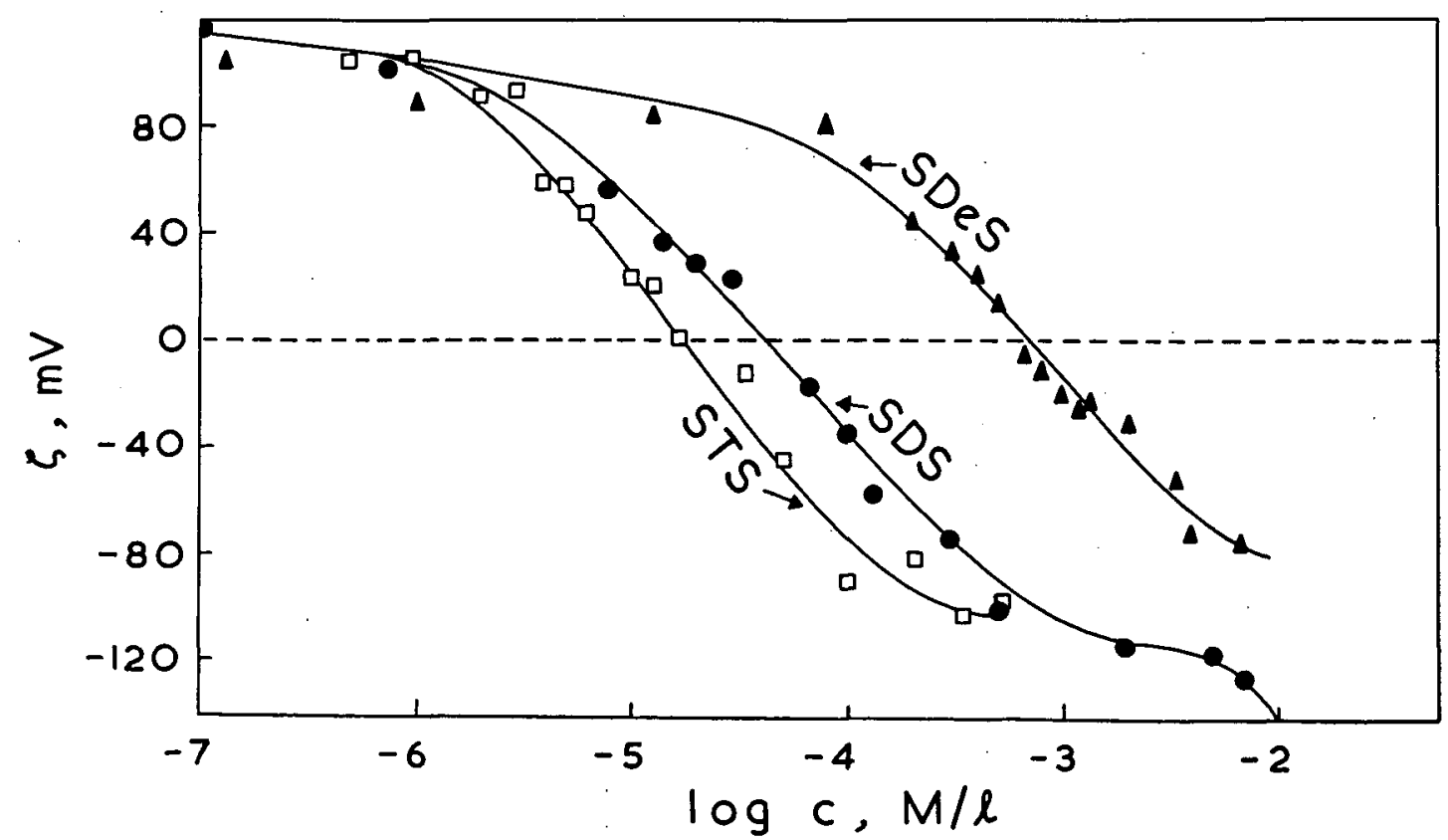

Fig. $13 \zeta$ vs. $\log$ concentration of surface active sulphates for positive silver iodide sols. 


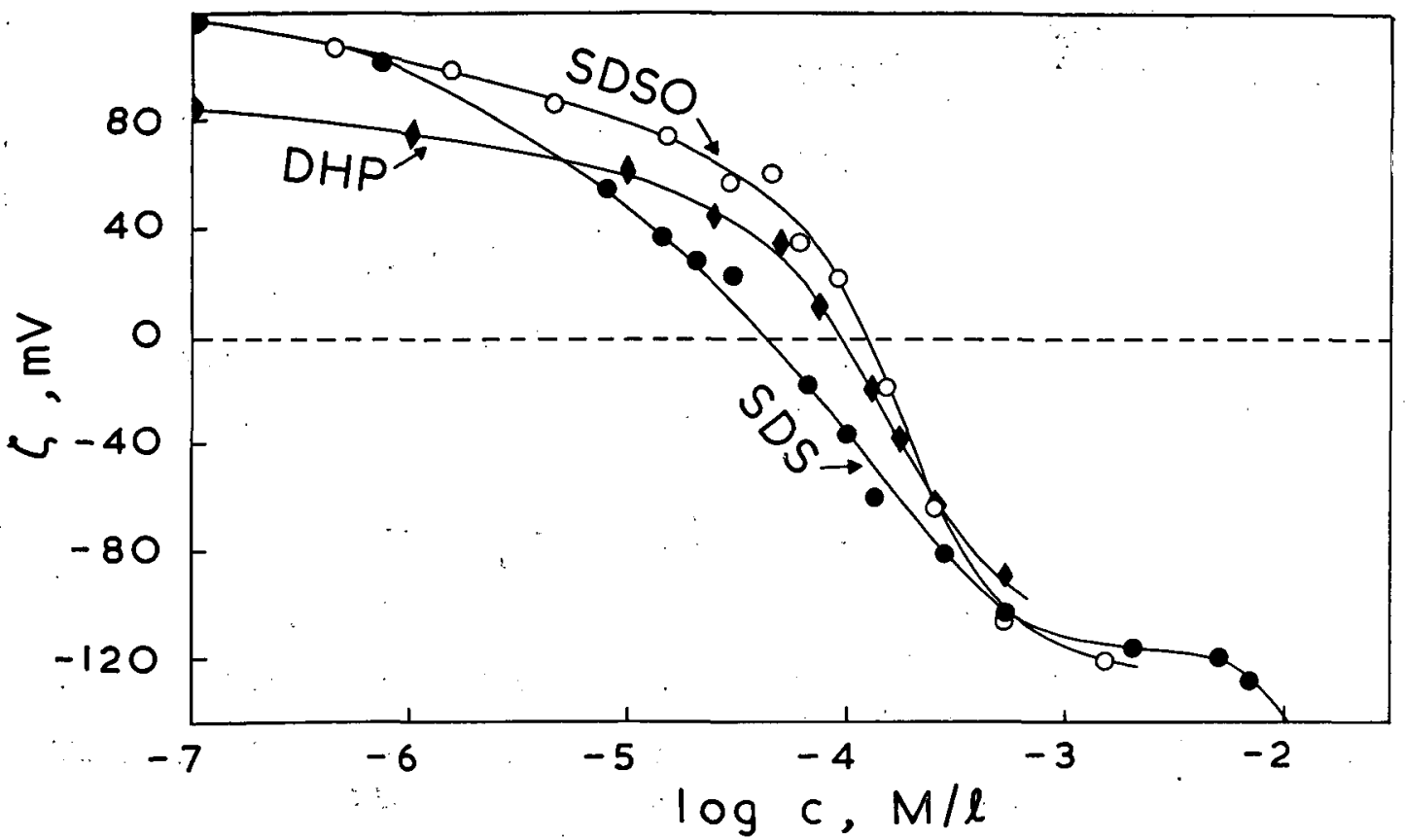

Fig. $14 \zeta$ vs. $\log$ concentration of dodecyl surface active agents for positive silver iodide sols.

(Na-decyl sulphate), SDS (Na-dodecyl sulphate), STS (Na-tetradecyl sulphate) を添加したときのら vs. $\log c$ 曲線である。曲線の形は Fig. 2 の $\psi_{1} v s$. $\log c$ 理論曲線とほぼ一致し, $\operatorname{SDeS}\left(\mathrm{C}_{10}\right), \operatorname{SDS}\left(\mathrm{C}_{12}\right)$, $\operatorname{STS}\left(\mathrm{C}_{14}\right)$ 之炭化水菜鎖が長くなると等電点 $c^{0}$ が低濃 度の方にずれるが， $c^{0}$ での曲線の公配は炭化水素銷の長 さ唖関係江一定である。式(35)，(36)から，- $\mathrm{CH}_{2}$ がます 之k, 従って吸着の自由エネルギー $\Delta G$ の絶対值が大き くなるが，一方吸着の site 数 わかる。

これに反して Fig. 14 亿示す SDs, SDSO (Nadodecyl sulphonate), DHP (Dodecyl dihydrogen phosphate）では炭化水素鎖住共に $\mathrm{C}_{12}$ であるが head groap がちがっている．乙机従って吸着 site 数 $\nu_{m}$ あちがってくるので $c^{0}$ での勾配が 3 者でちがった值を とっている. Table 1 には式 (35)，(36) を用いて $\zeta v s . \log$ $c$ 曲線から計算した $c^{0} ， k ， \nu_{m}$ ，および1イオンあたり の吸着断面積 $1 / \nu_{m}$, 吸着自由エネルギー $\Delta G$ を示した。
こてで $\psi_{1} \cong \zeta$ 乙仮定しているが，等電点 $c^{0}$ 附近では $\zeta \cong 0$ でありこの仮定は妥当である ${ }^{60,612}$. 又, 式 (27) 上り $\psi_{1} \cong \zeta=0$ では $\Delta \bar{G} \cong \Delta G$ とおくことができる．表中 SDBSO は Na-dodecyl benzenesulphonate を示す。

これらの実験結果加ら界面活性剂の吸着特性やStern 層の構造の検討を行なえる，そのくわしいことは省略す るが50,61)，とこで指摘しておきたいととは $1 / \nu_{m}$ が洌 えば sulphate では約 $500 \AA^{2}$ でその polar head の断 面積より 1 ケタ大きいことである。乙机は吸着層におい て界面活性剂が界面に平行に配列しているととを暗示す る. 刎論 AgI 表面で吸着 site は一様に分布している とは考えられず，吸着した電位決定イオンがてれに与っ ているととも十分想像できる。しかし，界面活性剤自身 の性質む $\nu_{m}$ の值化効くことや， $\nu_{m}$ 值が電位決定イオ ンの数より大きいことは，他仙む吸着の site として効 く部分が表面に分布していることを示している。

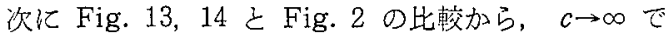
$\zeta$ 絶対值は理論値より大きい值に収れんしている.

Table 1 The adsorption of surface active agents on positive silver iodide sols.

\begin{tabular}{l|c|c|c|c|c}
\hline Surface active agent & $\begin{array}{c}c^{0} \\
\mathrm{M} / 1\end{array}$ & $\begin{array}{c}k \\
\mathrm{M} / 1\end{array}$ & $\begin{array}{c}\nu_{m} \\
\mathrm{~cm}^{-2}\end{array}$ & $\begin{array}{c}1 / \nu_{m} \\
\AA^{2}\end{array}$ & $\begin{array}{c}-\Delta G \\
\mathrm{cal} / \mathrm{M}\end{array}$ \\
\hline SDeS & $5.98 \times 10^{-4}$ & $6.80 \times 10^{3}$ & $1.94 \times 10^{13}$ & 516 & 7,560 \\
SDS & $4.21 \times 10^{-5}$ & $6.41 \times 10^{4}$ & $1.94 \times 10^{13}$ & 516. & 8,880 \\
STS & $1.68 \times 10^{-5}$ & $1.61 \times 10^{5}$ & $1.94 \times 10^{13}$ &. & 516 \\
SDSO & $1.20 \times 10^{-4}$ & $7.93 \times 10^{3}$ & $2.91 \times 10^{13}$ & 344 & 9,410 \\
SDBSO & $1.45 \times 10^{-5}$ & $9.17 \times 10^{4}$ & $2.48 \times 10^{13}$ & 404 & 7,650 \\
DHP & $9.50 \times 10^{-5}$ & $7.35 \times 10^{4}$ & $1.62 \times 10^{13}$ & 617 & 9,080 \\
\hline
\end{tabular}


III の理諭は Langmuir 型の 単分子層吸着を仮定して 導いたすのであり，実験之理論のこの不一致は高濃度で はこのモデルが不十分で第 2 吸着層の形成在仮定すべき ことを示している。との第2 吸着層にたいする吸着 site 数 $\nu_{2 m}$ 上吸着自由エネルギー $\Delta G_{2}$ を実験值から計算す ると, STSにつき次の值がえられた，

$$
\begin{aligned}
\nu_{2 m} & =8.75 \times 10^{12} \mathrm{~cm}^{-2} \\
\Delta G_{2} & =-5,655 \mathrm{cal} / \mathrm{M}
\end{aligned}
$$

Table $1 の \Delta G=-9,410 \mathrm{cal} / \mathrm{M}$ と比較して, 第 2 吸着 層の化学的吸着自由エネルギー $\Delta G_{2}$ の絶対值 は約 4 $\mathrm{kcal} / \mathrm{M}$ 小さい. Mysels ら ${ }^{62)}$ の寒験によると, SDS の dimer 形成の自由エネルギーは約 $3 \mathrm{kcal} / \mathrm{M}$ である. STS では SDS より $\mathrm{CH}_{2}$ 基が 2 つ多いから，上の $\Delta G_{2}$ の值のオーダーから考えて，おそらく第 1 吸着層のSTS 分子が第 2 吸着層の吸着 site 亡なり，炭化水素鎖間の van der Waals 引力によって吸着が起るのであ万う. 又, Table 1 のSTS 以ついての值 $\nu_{m}=1.94 \times 10^{13} \mathrm{~cm}^{-2}$ と上の $\nu_{2 m}$ 值が仿とんど等しい order を示しているこ とも上の仮説を支持するものと考えられる。

4 対イオン結合

第 2 吸着層の活性剂イオンはどんな配向をしているだ ろうか？てれ対して次の対イオン結合の実験は有力 な知見を与える

Fig. 13 より正 AgI ゾル (pAg 3) に $c=10^{-4} \mathrm{M} / 1$ のSTS を加える之粒子は負に带電し $\left(\zeta^{*}=-89 \mathrm{mV}\right)$, ゾルは安定で (次章)，表面は第 2 吸着層でおおわれて いる. 乙のとき第 1 と第 2 吸着層の STS イオンの数を $\nu, \nu_{2}\left(\mathrm{~cm}^{-2}\right)$ とすると

$$
\begin{aligned}
& \nu=\frac{\nu_{m} k c}{1+k c}, \quad \nu_{2}=\frac{\nu_{2 m} k_{2} c}{1+k_{2} c} \\
& \zeta^{*}-\zeta=\frac{4 \pi a e}{\varepsilon(1+\kappa a)}\left(\nu+\nu_{2}\right)
\end{aligned}
$$

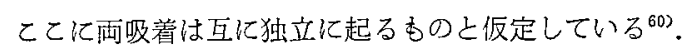
下添字 2 は第 2 吸着層に関する量を示し前節に得た， $\nu_{2 m}$ と $k_{2}=\exp \left(\Delta \bar{G}_{2} / k T\right) / 55.6$ の数值及び $c=10^{-4}$ $\mathrm{M} / 1$ を代入して $\nu_{2}$ を計算すると次式をうる,

$$
\nu_{2}=4.5 \times 10^{12} \mathrm{~cm}^{-2} .
$$

さて，との状態のゾルに種々漂度 $c_{\theta}$ の電解質を加え たとき，Fig. 15 に示すようにらが正の方向に変化する ことが実験的に示された。このととは第2 吸着層のSTS の polar head - $\mathrm{SO}_{4}-$ と加えた電解質のカチオンとの 結合が起るためと理解される。一般にこのような対イオ ン結合によるらの変化は66,70), 原理的に洁III示した Stern 層吸着と同じ理論式で論じることができるから，

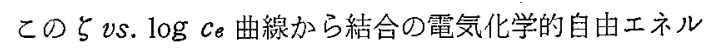
ギー $\Delta \bar{G}$ 乙結合 site 数 $\nu_{m}$ を求めることができる. か くして求めた Table $2 の \nu_{m}$ は，カチオン種が非常に

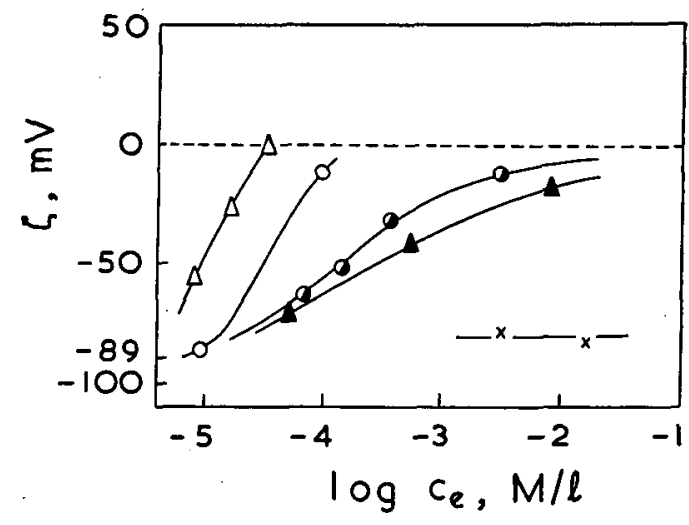

Fig. $15 \zeta$ vs. $\log$ concentration of electrolytes for silver iodide sols covered with $10^{-4} \mathrm{M} / \mathrm{I}$ STS. $\triangle \mathrm{La}\left(\mathrm{NO}_{3}\right)_{3} ; \quad \mathrm{OBa}\left(\mathrm{NO}_{3}\right)_{2} ; \quad \mathrm{Ca}\left(\mathrm{NO}_{3}\right)_{2} ;$ $\triangle \mathrm{CdSO}_{4} ; \times \mathrm{NaNO}_{3}$.

らがっです警くべき一致を示し，さらに $\nu_{m}$ の平均值 $4.23 \times 10^{12} \mathrm{~cm}^{-2}$ は上に求婂た $\nu_{2}$ 之非常に上く一致して いる.このととは第 2 吸着層の STS イオンがカチオン 結合の site となっているととを示す実験事䒠である.

結合の自由エネルギー $\Delta G$ は式(扐によって求めた. ここで一般にイオンにおいては静電項 $\left|z e \phi_{1}\right|$ に比して 分極項 $\left|b \psi_{1}{ }^{2}\right|$ は $\left|\psi_{1}\right|$ の小さい間は無視できるから， $\psi_{1}=\zeta=-0.039 \mathrm{~V}$ とおいて $\Delta G=\Delta \bar{G}-915 z$ によって $\Delta G$ を求めた. Table 2 に与えたての $\Delta G$ 值は, 刘応 する tetradecyl sulphate の塩の溶解度 ${ }^{652}$ の大きさと 明らかな相関性を示している. 即ち, 塩が溶解しにくい あのほど $-\mathrm{SO}_{4}$ とそのカチオンとの結合力は大きく，

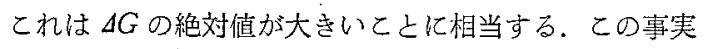
は，上に示した第 2 吸着層の tetradecylsulphate 1 オンにおける対イオン結合が sulphate headを site として起っているとと, すなわち第2 吸着層では polar head $-\mathrm{SO}_{4}-$ が溶液側に向いているととの証明よなって いる.

\section{VII 凝集速度の測定}

1 光学的測定法

疎液性コロイドに電解質を加えて凝集を起すと垃子体 皘が増す. 從って 分光光度計と自動記録計によって光

Table 2 The counter ion binding of silver iodide sols covered with $10^{-4} \mathrm{M} / 1$ STS. $a=100 \AA, \zeta^{*}=-89 \mathrm{mV}$.

\begin{tabular}{c|c|c}
\hline Counter ion & $\begin{array}{c}\nu_{m} \\
\left(\mathrm{~cm}^{-2}\right)\end{array}$ & $\begin{array}{c}-\Delta G \\
(\mathrm{cal} / \mathrm{M})\end{array}$ \\
\hline La $^{+++}$ & $3.45 \times 10^{12}$ & 5,880 \\
$\mathrm{Ba}^{++}$ & $5.25 \times 10^{12}$ & 5,650 \\
$\mathrm{Ca}^{++}$ & $4.24 \times 10^{12}$ & 5,730 \\
$\mathrm{Cd}^{++}$ & $3.96 \times 10^{12}$ & 5,520 \\
\hline Average & $4.23 \times 10^{12}$ & \\
\hline
\end{tabular}



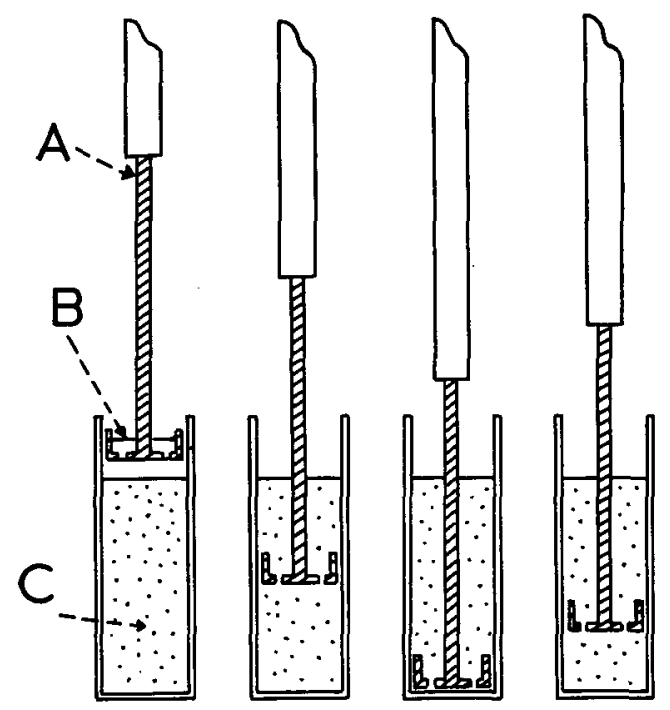

Fig. 16 Rapid mixing for the coagulation experiments. A, mixer; B, coagulating agent; $C$, sol.

透過率の経時変化を調べて凝集速度を求めることができ $3^{76)}$

Perspex 又仿石英製の光学セル（光学路程 $l=1 \mathrm{~cm}$ ) にゾル $3 \mathrm{ml}$ を入れて Unicam SP 600 の分光光度計に セットする，底に2つの小孔をあけた Perspex 製の mixer に凝集剂 $0.1 \mathrm{ml}$ 在入れ，乙れを速や加光学セ ル中にさし込んで引き上げる (Fig. 16)，するとセル中 のゾルが小孔を通過往復するから，この1回の操作でゾ ルと凝集剂が完全に混合する. この時刻を $t=0$ に上

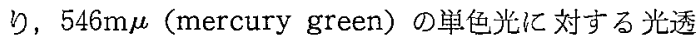
過率 $I / I_{b}$ の経時变化を追跡する.こてで $I_{b}$ は入射光, $I$ は透過光の強度で, 蒸留水で $I / I_{i}=1$ 亡する.

Lambert の法則より

$$
I=I i \exp (-\tau l)
$$

ここで $l=1 \mathrm{~cm}$ で， $\boldsymbol{\tau}$ は turbidity であり光学密 度を $H$ とするよ。

$$
\tau=2.303 \log \left(I_{L} / D\right)=2.303 \mathrm{H}
$$

光散乱に関する Rayleigh の理論によると， consumptive absorption がなくかつ $a<0.05 \lambda$ の条件では次式が成立する,

$$
\begin{aligned}
& \tau=Y N v^{2} \\
& Y=\frac{24 \pi^{3} \mathrm{n}^{\prime 4}}{\lambda^{4}} \cdot\left(\frac{\mathrm{n}^{2}-\mathrm{n}^{\prime 2}}{\mathrm{n}^{2}+2 \mathrm{n}^{2}}\right)
\end{aligned}
$$

$N$ は単位体積中のゾル粒子数, $v$ は管一粒子の体 積, $\mathrm{n}$ 上 n’ は粒子と媒質の屈折率, $\lambda$ は単色光の 真空中での波長である．ここで，Nvはゾルの体積 濃度で，与えられたゾルについては凝集状態に依存 せず一定である，促って (84)より，凝集とともにv
がますとて（又は $H ）$ が增大する.

先の正 AgI ゾル (pAg 3) に種々滺度の硫酸ナ トリウムを加えたときの $\Delta H$ vs. $t$ 湊験曲線を Fig. 17 に示す ${ }^{63)}$. ここに $\Delta H \equiv H(t)-H(O)$ である.

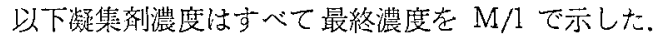
明ら加㠜集速度は電解質灌度 $c_{e}$ ととむに増大し て, ある一定値に収れんしている，乙こで $t \rightarrow 0$ で の曲線の公配の逆数の対数 $\log (d t / d \Delta H)_{t=0}=\log$ $(d t / d H)_{t=0}$ 之 $\log c_{e}$ の関係を求めると, 種々の 電解筫につき Fig. 18 の曲線がえられた. 一般に 凝集速度が小さいにどそのゾルは安定と云えるか ら，Fig. 18 はゾルの安定性に及括す電解犋の效果 を表扎している，乙机らの曲線で扣かるように，正 のゾルの㠜集には加えた電解質のアニオン成分が支 配的役割を演じ，その原子価が大きいはど効果が大 きい.これは Schulze-Hardy の法則に多ならな い( $\mathrm{V}$ 参照).

Fig. 18 の各曲線は $\log c e$ がますとまず直線的 亿低下し，ある濃度をこえると水平な直線に移る，低濃 度での直線部分は緩慢凝集を示し ( $\mathrm{V}$ 参照)，乙の直線 の延長上高濃度での水平線 と交点によって凝集濃度 (凝結佂) $\mathrm{Ce}^{+}$を定義できる ${ }^{50)}$. Table 3 亿正 AgI ゾ ル (pAg 3) における凝集濃度を示した。ふつうの電解 質ではこれより高濃度側では凝集速度は加えた電解質の 種類に繁閣係に一定であり，精子間斥力の働いていない 急速凝集 (II 参照) が起っているととを示す3).

クエン酸イオンの場合にあ $c_{e}$ をますと緩慢凝集加ら 急速凝集に移るが，凝集濃度をこえるとふたたび䌅慢凝 集が起る，かくて曲袙はある浱度で極小を示し，高濃度 での安定化が見られる (Fig. 18)，イオン性界面活性澹

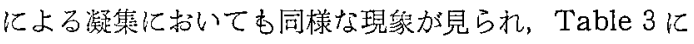
示すようにかかる場合の㠜集濃度が異常に低いこととあ

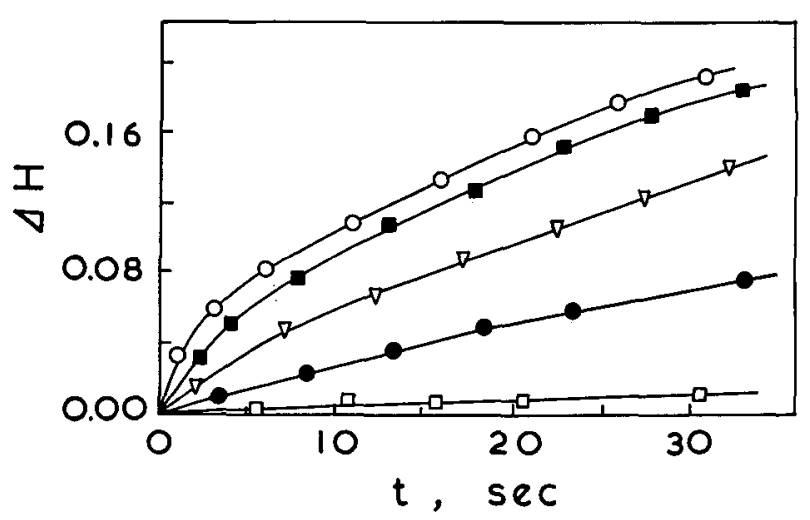

Fig. $17 \Delta$ optical density vs. time for coagulation of positive silver iodide sols by sodium sulphate. AgI sol: $5 \times 10^{-4} \mathrm{M} / 1, \mathrm{pAg} 3, \mathrm{a}=100 \AA . \mathrm{Na}_{2} \mathrm{SO}_{4}: \square 6.67$ $\times 10^{-4}, \quad 1.00 \times 10^{-3}, \quad \nabla 1.33 \times 10^{-3}, \quad 2.00 \times 10^{-3}$, $3.00 \times 10^{-2} \mathrm{M} / 1$. 


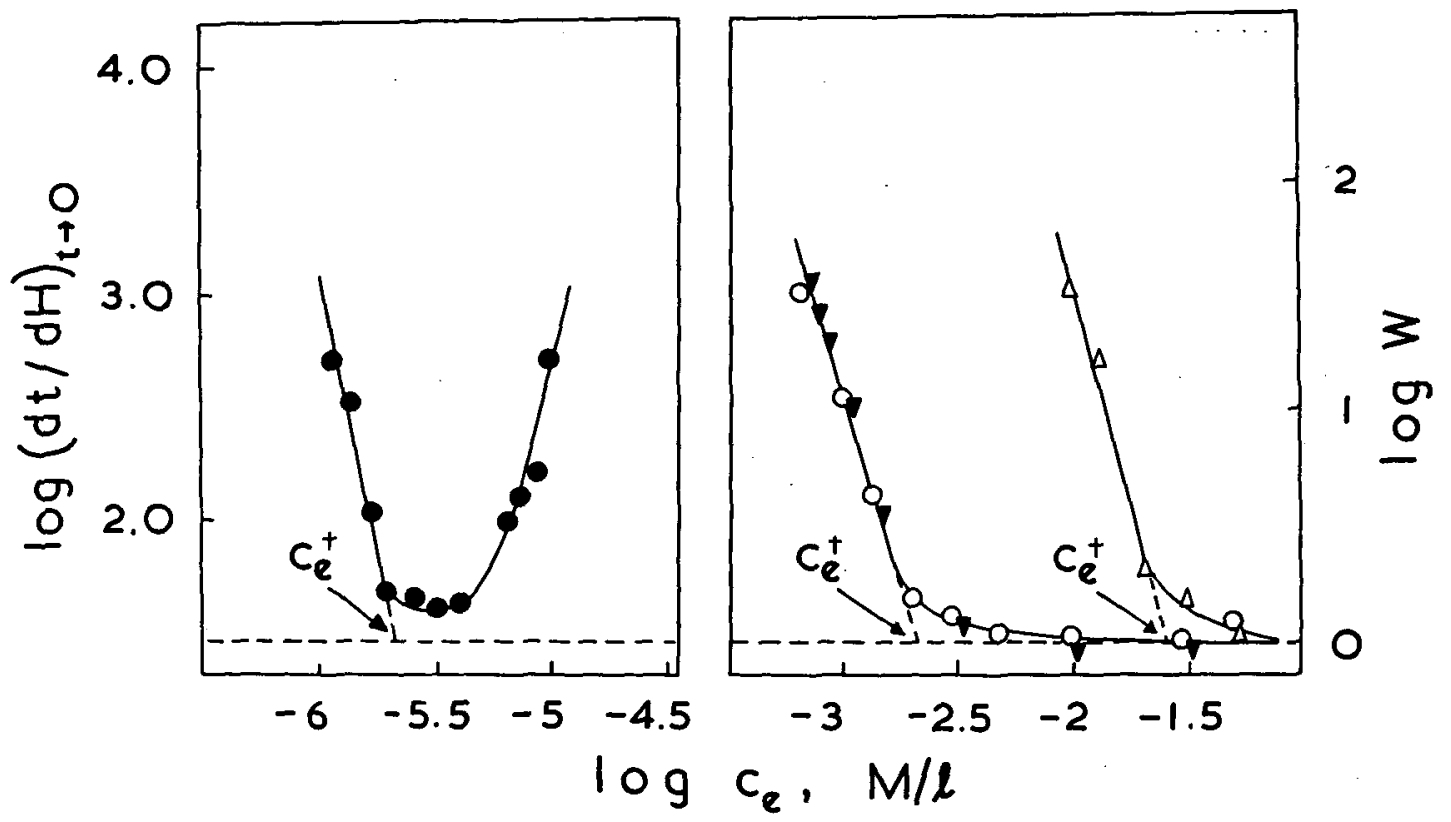

Fig. 18 Coagulation of positive silver iodide sols by electrolytes.

$\triangle \mathrm{KNO}_{3} ; \nabla \mathrm{MgSO}_{4} ; \mathrm{ONa} \mathrm{SO}_{4} ; \mathrm{Na}_{3}$ citrate.

わせて考觉ると，上の $\mathrm{NO}_{3}^{-}$や $\mathrm{SO}_{4}^{--}$の低分子イオン と全くちがった凝集機構が起っていることは明らかであ る.

\section{2 安定度の計算}

式 (84) と (9)より急速凝集では次式が成立する.

$$
\begin{aligned}
\frac{d \tau}{d t}=Y N^{2} v^{2} \frac{d N^{-1}}{d t} & =Y k_{r} N^{2} v^{2} \\
& =Y k_{r} w^{2} / \delta^{2}
\end{aligned}
$$

ここに $w$ はゾル溲度 $(\mathrm{g} / \mathrm{ml}), \delta$ は粒子を構成する物質 の密度 $(\mathrm{g} / \mathrm{ml})$ である. 対数をとると、

$$
\log \left(\frac{d H}{d t}\right)_{r}=\log \left(\frac{K k_{r} w^{2}}{2.303 \delta^{2}}\right)
$$

Fig. 18 の結果では正 AgI ゾル (pAg 3) では ${ }^{54,60)}$

$$
\log (d H / d t)_{r}=-1.56
$$

Table 3 Coagulation of positive silver iodide sols.

\begin{tabular}{l|c|c}
\hline Coagualting agent & $\begin{array}{c}\text { Coagulation concentration (M/1) } \\
\text { Extrapolation to } \\
\text { log } W=0\end{array}$ & $\begin{array}{c}\text { Minimum on log } \\
\text { W vs. log c curve }\end{array}$ \\
\hline $\mathrm{KNO}_{3}$ & $\begin{array}{c}2.46 \times 10^{-2} \\
\mathrm{Na}_{2} \mathrm{SO}_{4}\end{array}$ & \\
$\mathrm{MgSO}_{4}$ & $2.14 \times 10^{-3}$ & \\
$\mathrm{Na}_{3}$ citrate & $2.14 \times 10^{-3}$ & \\
$\mathrm{SDeS}$ & $3.80 \times 10^{-6}$ & $2.8 \times 10^{-6}$ \\
$\mathrm{SDS}$ & $2.35 \times 10^{-5}$ & $7.42 \times 10^{-4}$ \\
$\mathrm{STS}$ & $5.70 \times 10^{-6}$ & $5.25 \times 10^{-5}$ \\
$\mathrm{SDSO}$ & $5.13 \times 10^{-5}$ & $1.26 \times 10^{-5}$ \\
$\mathrm{SDBSO}$ & $1.15 \times 10^{-5}$ & $3.82 \times 10^{-5}$ \\
$\mathrm{MOT}$ & $5.00 \times 10^{-6}$ & $2.40 \times 10^{-5}$ \\
DHP & $1.82 \times 10^{-5}$ & $2.33 \times 10^{-6}$ \\
\hline
\end{tabular}

である。この值及び $w=5 \times 10^{-4} \mathrm{M} / 1=1.175 \times 10^{-4} \mathrm{~g} / \mathrm{ml}$, $Y=3.70 \times 10^{19} \mathrm{~cm}^{-4}, \delta=5.67 \mathrm{~g} / \mathrm{cm}^{3}(\mathrm{Ag} \mathrm{I})$ を式(87) と代 入すると，

$$
k_{r}=5.04 \times 10^{-12} \mathrm{~cm}^{3} \mathrm{sec}^{-1}
$$

なる実験值をうる。 ここに $\mathrm{n}=2.22(\mathrm{AgI}), \mathrm{n}^{\prime}=1.33$ (水)， $\lambda=5.46 \times 10^{-5} \mathrm{~cm}$ を(85)に代入して $Y$ を求めた. かくしてえられた $k_{r}$ 值を(13) の理諭值 $k_{r}=5.4 \times 10^{-12}$ $\mathrm{cm}^{3} \mathrm{sec}^{-1}$ と比較するとその一致が驚くへくよいととが わかる。これは幾分幸運上も考无られるが，少なくとあ この光学的测定法の妥当性を示すに十分な験証と云える だろう。

次にゾルの安定度 $W$ を次式で定義しよう,

$$
W=\frac{(d H / d t)_{r}}{(d H d t)}=\frac{(d \tau / d t)_{r}}{(d \tau / d t)}
$$

下添字 $r$ は粒子間斥力劣除いたとき起る急速凝集を示 す.急速凝集では $W=1$ となり，緩慢凝集では $W>1$, $d H / d t=0$ なる ideal な場合は完全に安定なゾルで $W$ $=\infty$ である.

$$
\begin{aligned}
& \text { 式 (89) を刘数で示すと } \\
& \log W=\log (d t / d H)-\log (d t / d H) r
\end{aligned}
$$

となり，右辺第 2 項はゾルの種類，濃度，光源の波長な よ゙で定まる定数である. 上の正の AgI ゾル (pAg 3， $\left.w=5 \times 10^{-4} \mathrm{M} / 1\right)$ では $\log (d t / d H)_{r}=1.46$ であり, こ の値によって計算した $\log W を$ Fig. 18 の右側の䅠朝 に示してある.

かく $\log W$ を定義すると Fig. 18 の緩慢凝集領域で 


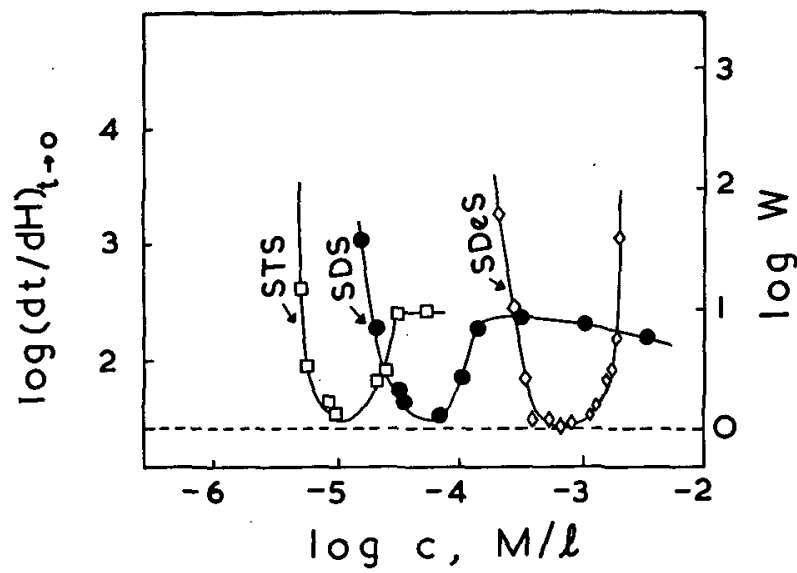

Fig. 19 Log stability vs. log molar concentration for alkyl sulphates.

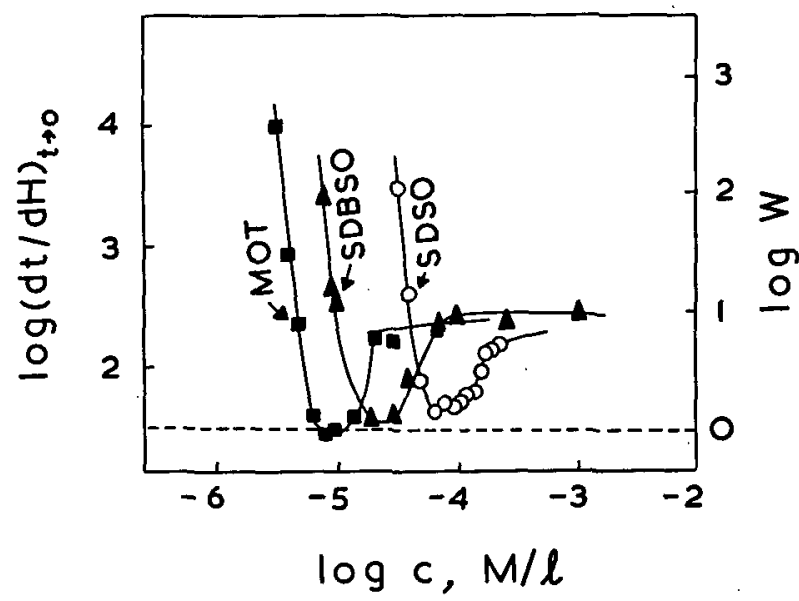

Fig. 20 Log stablity vs. $\log$ molar concentration for surface active sulphonates.

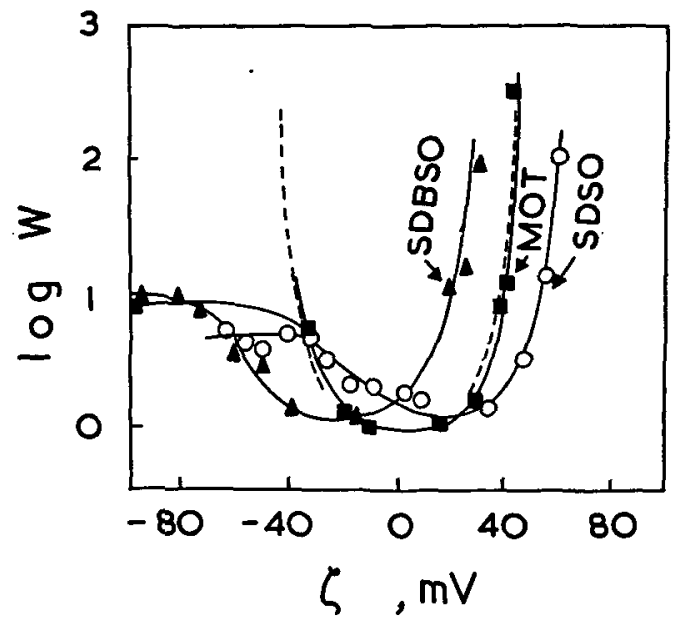

Fig. 21 Log stability vs. $\zeta$ curves for surface active sulphonates. -..theoretical curve for $A=3 \times 10^{-12} \mathrm{erg}$.
の $\log W$ vs. $\log c_{8}$ 直線の公配之式(73)，(74)を用 いて $\gamma^{2}$ と van der Waals 定数 $A$ を求加ると ができる. $\mathrm{KNO}_{3}, \mathrm{Na}_{2} \mathrm{SO}_{4}$ の場合の勾配から夫々 $A=0.8 \times 10^{-12}, 1.1 \times 10^{-12} \mathrm{erg}$ cいう值がえられ 罗当な数值である (IV 参照).

\section{3 吸着凝集速度}

正 AgI ゾル (pAg 3) に SDeS, SDS, STS, SDSO, SDBSO, MOT (Na-dioctyl sulphosuccinate) を添加したとき $\log W$ vs. $\log c$ の曲線 を Fig. 19，20 亿示す ${ }^{-30\rangle}$. 曲線の形は Fig. 10 の 理論曲線とよく一致している。すすおち界面活性剂 濃度 $c(\mathrm{M} / \mathrm{l})$ がますと $\log W$ 㹥まず低下し，極 小を経て再び增大し，一定値に收㣗えする。，同じ polar head（たとえばーSO4-）をもつ界面活性剂 では炭化水菜鎖が長いほど極小の位置が低濃度にあ る. Fig. 13，14 と此較してわかるように，これは $k$, 従って吸着自由エネルギーの絶対值, が大きい ほざ等電点 $c^{0}$ が低濃度にずれるからである。

Fig. 21 は $\log W$ vs. $\zeta$ の例で, 破線は式(76)で $\psi_{1}=\zeta$ と拈いて求めた理諭曲線である，とこに奏験 曲線と合うように $A=3 \times 10^{-12} \mathrm{erg}$ とおいた。 理

の 論亡実験曲線の形はよく一致しているが， $\log W$ の極小 $\left(\log W_{m \ell n}\right)$ を与えるら值は必らずしすゼ ロでない. Table 4 に $\log W_{m i n}$ および極小を与 えるとm的示した。

二つの粒子が近づくとき，両者の二重層間の相互 作用によって Stern 層棈造に変化が起ることは十 分考えられる，徉って綮密な理論では，搪散二重層 の重嘼のみでなく，二重層の能率の相互作用を考虑 しなければならない，著者の計算によると 間の自由エネルギー $F$ は次式で与えられる，

$$
\begin{aligned}
& F=\left(\frac{1+p}{1+2 p}\right) \frac{\left(\sigma+\sigma_{m i n}\right)^{2}}{2 h}+\frac{\sigma^{2} m i n}{2 h} \\
& \sigma_{m i n}=\frac{m}{2 h} \cdot \frac{1}{1+p}
\end{aligned}
$$

ここに $2 h$ は表面間の距離 (Fig. 3), $p=\alpha / 8 h^{3}$ で, $\alpha$ は二重層の effective な分極率である。係数 $(1+\mathrm{p})$

Table 4 Deviations of the stability minimum from ideality.

\begin{tabular}{c|c|c}
\hline $\begin{array}{c}\text { Surface active } \\
\text { agent }\end{array}$ & $\log W$ min & $\zeta_{\text {min }}(\mathrm{mV})$ \\
\hline SDeS & 0.02 & +15 \\
SDS & 0.02 & -15 \\
STS & 0.08 & +20 \\
SDSO & 0.08 & +20 \\
SDBSO & 0.06 & -13 \\
MOT & 0.00 & +4 \\
DHP & 0.00 & 0 \\
\hline
\end{tabular}




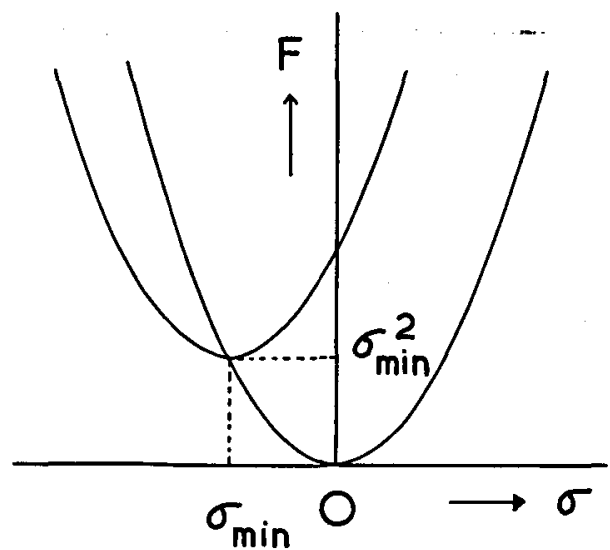

Fig. 22 Shift of the free energy minimum due to the Stern layer interaction.

$/(1+2 p)$ は 1 に近いが 1 より小さい值をとり， $m$ は単位界面積あたりの永久双極子能率の大きさであ る. 式(90)は $m$ と $\alpha$ を考虑すると，2平面の相亘作

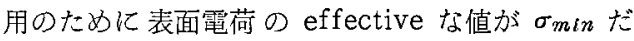
け座標移動すると同時に，自由エネルギー，従って ゾル安定度が $\sigma^{2}$ min (>0)に比例する值だけ增大 するととを示している (Fig. 22). 事奏 Fig. 21 および Table 4 でわかるように， は $\log W_{m i n}=0$ であり， $\zeta_{m i n} \neq 0$ なら $\log W_{m i n}$ $>0$ となっている.

吸着凝集では要するに粒子の帯電にたいして反対 符号のイオンが特異吸着をして $\left|\psi_{1}\right|$ が低下する。 従ってたとえば virus stability ${ }^{643}$ ，蛋白安定度の $\mathrm{pH}$ 依存性なども同様な機構で説明できる。Fig. 23，24 は一定濃度の STS $\left(c=10^{-3} \mathrm{M} / 1\right)$, SDBSO $\left(c=9 \times 10^{-4} \mathrm{M} / 1\right)$ 亿種々の電解質 (濃度 $c e$ ) を加え たよき生成する石ケン溶液 (tetradecyl sulphate 又は dodecyl benzenesulphonate) の金属塭)の 混合後 $90 \mathrm{sec}$ での光学密度 $H$ と，粒子の電気泳 動速度 $U$ とを $\log c_{e}$ に対して図示したものであ $3^{65,77)}$. Th p La 塩で $H$ の極大を与える $c_{e}$ で $\left|\psi_{1}\right|=0$ 己なっている.ふつつ 2 価カチオンでは対 イオン結合による電荷の反転は見られないが，Ca や Ba は他の 2 価力チオンより結合力が大きいこ そがわかる。

VI.4 において STS の第2 吸着層で蔽わ机た

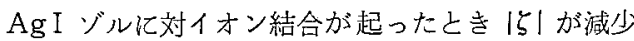
する現象をのべたが，これに刘応して $\log W$ の変 化む起ることが実験的に示された ${ }^{30,63,65)}$. Fig. 25 はその $\log W$ vs. $\kappa a$ 曲線である。 これらの曲線 群を見机ば，電解質のカチオン成分の種類，〈わ しく云えば結合自由エネルギーの大小，によって Schulze-Hardy 凝集，吸着凝集，および雨方の各

昭和 39 年 4 月

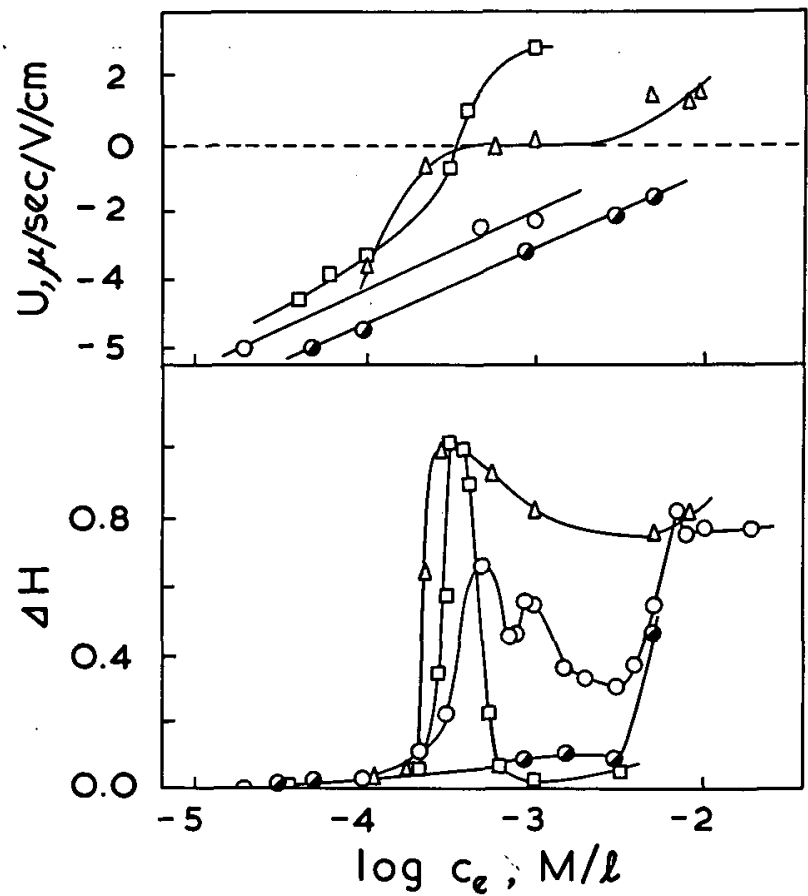

Fig. 23 Formation of tetradecyl sulphate salts.

A, Electrophoretic mobility $U, \mu / \mathrm{sec} / \mathrm{V} / \mathrm{cm} v s . \log$ molar concentration of added electrolytes.

$\mathrm{B}$, Optical density, $90 \mathrm{sec}$ after mixing, vs. $\log$ molar concentration of added electrolytes.

$\square \mathrm{Th}\left(\mathrm{NO}_{3}\right)_{4}, \triangle \mathrm{La}\left(\mathrm{NO}_{3}\right)_{3}, \mathrm{OBa}\left(\mathrm{NO}_{3}\right)_{2}, \mathrm{Ca}\left(\mathrm{NO}_{3}\right)_{2}$.

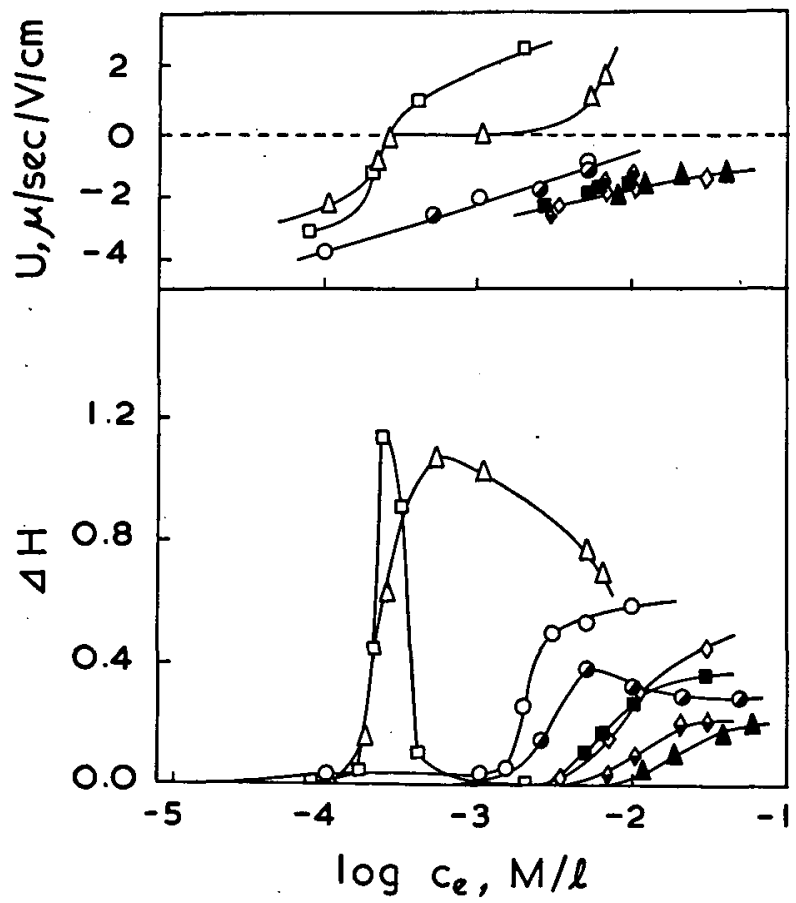

Fig. 24 Formation of dodecyl benzenesulphonate salts.

A, Electrophoretic mobility $U, \mu / \mathrm{sec} / \mathrm{V} / \mathrm{cm}$ vs. $\log$ molar concentration of added electrolytes.

B, Optical density, $90 \mathrm{sec}$ after mixing, vs. log molar concentration of added electrolytes. $\square \mathrm{Th}\left(\mathrm{NO}_{3}\right)_{4} ; \triangle \mathrm{Ia}\left(\mathrm{NO}_{3}\right)_{3} ; \bigcirc \mathrm{Oa}\left(\mathrm{NO}_{3}\right)_{2} ; \mathrm{Ca}$ $\left(\mathrm{NO}_{3}\right)_{2} ; \diamond \mathrm{MgSO}_{4} ; \Delta \mathrm{CdSO}_{4} ; \mathrm{ZnSO}_{4} ; \diamond \mathrm{MnSO}_{4}$. 


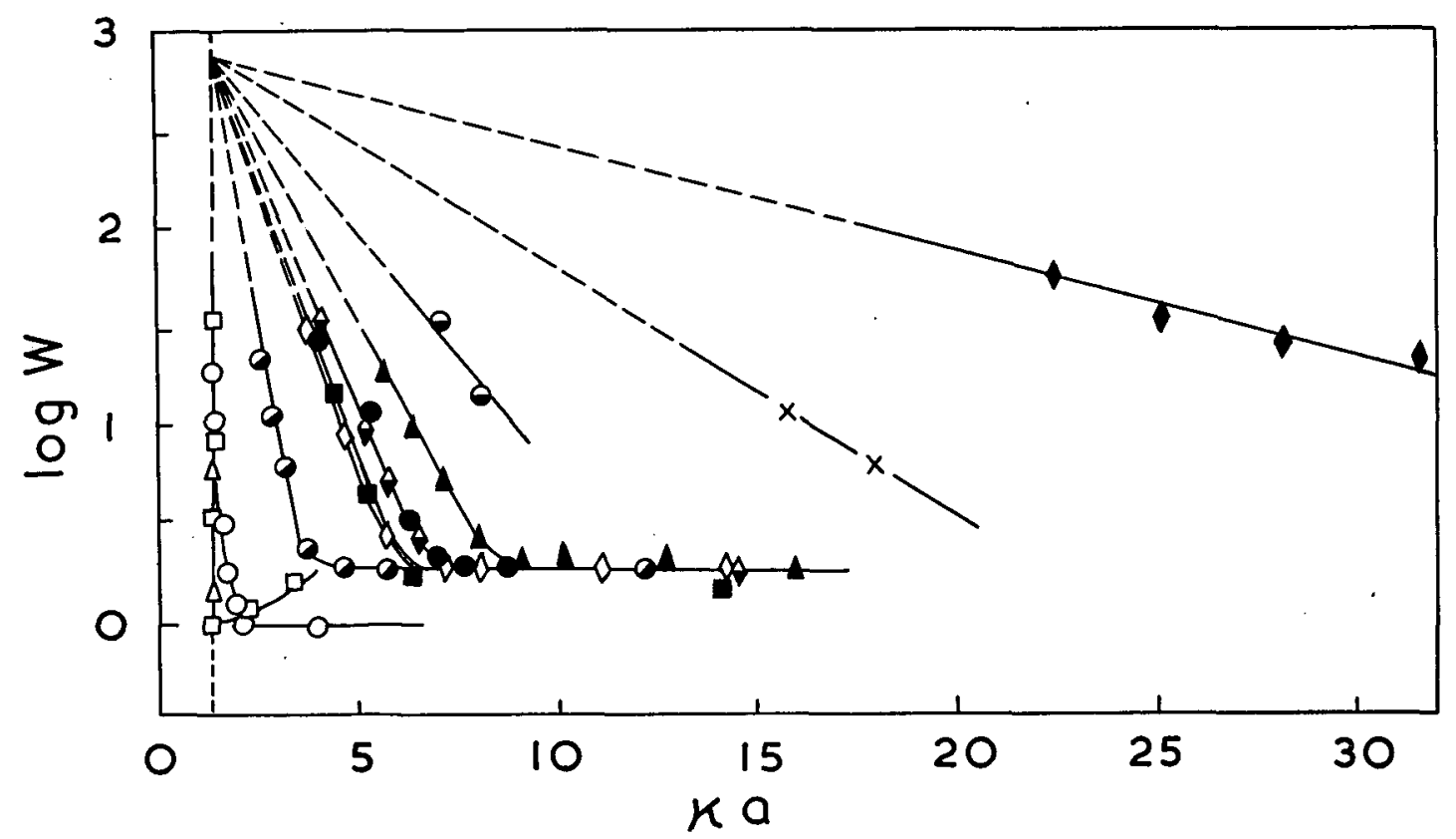

Fig. 25 Log stability vs. $\kappa$ a curves for AgI sols covered with STS.

- $\mathrm{LiNO}_{3} \odot \mathrm{UO}_{2}\left(\mathrm{NO}_{3}\right)_{2} \bigcirc \mathrm{Ba}\left(\mathrm{NO}_{3}\right)_{2} \square \mathrm{Th}\left(\mathrm{NO}_{3}\right)_{4} \times \mathrm{NaNO}_{3} \boldsymbol{\Delta} \mathrm{CdSO}_{4}$

( $\mathrm{Ca}\left(\mathrm{NO}_{3}\right)_{2} \triangle \mathrm{La}\left(\mathrm{NO}_{3}\right)_{3} \odot \mathrm{KNO}_{3} \quad \mathrm{ZnSO}_{4} \diamond \mathrm{MgSO}_{4} \uparrow \mathrm{MnSO}_{4}$

種の機構が起りうることがわかる．これは V·5 の一般 に爷配されることがわかった．しかし，Overbeek一派 凝集理諭の実例之見てよいだるう。

䜣 水銀滴の合一

1 水銀滴の合一之凝集理論

疎液性コロイドの安定性が Stern 電位々電解質濃度
および著者らのこの凝集理論にたいするゾルを用いた験 証では，ふつう Schulze-Hardy と吸着凝集が別々に 論じら机，しかもらのような熱力学的には綮密に定義 できない量を用いて議論が行なわれる，そとで，表面の

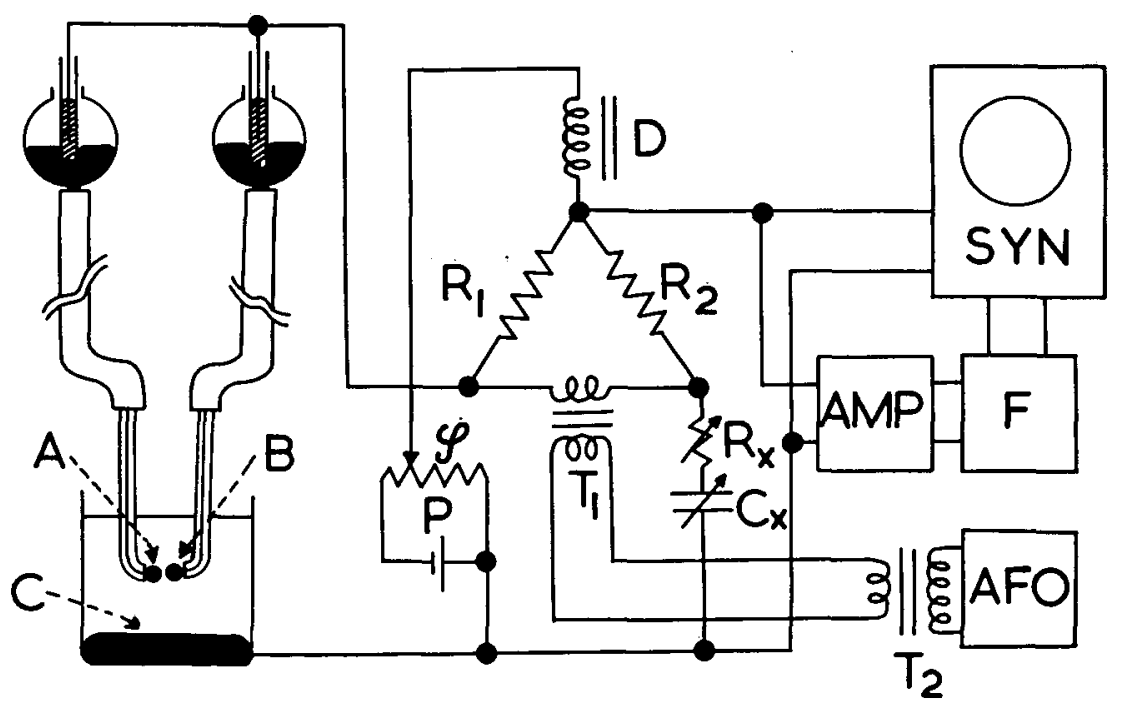

TDME

Fig. 26 The coalescence experiment of mercury droplets. A, B, mercury droplets; C, reference (pool) electrode; $D$, choke coil; $F$, filter circuit; $P$, potentiometer; $R_{1}, R_{2}$, resistors; $T_{1}, T_{2}$, transformers $; R_{\mathbf{x}}$, standard variable resistor; $C_{\mathbf{x}}$, standard variable capacitor; AMP, ampli. fier; AFO audiof requency oscillator, 1,000 cps; SYN, synchroscope; TDME, twin dropping mercury electrodes. 


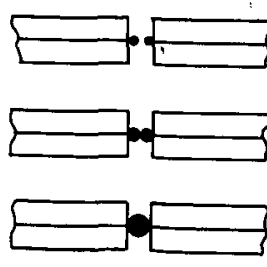

A

Fig. 27 The behaviour of. twin mercury droplets. A, coalescence; B, repulsion.

電位 $\psi_{0}$ とイオン強度とを紧密傹規定して各因子が 粒子間相互作用に如何に影響するかを統一的仁論じ る目的で，溶液中の $2 つ の$ 水銀滴の合一条件を調心 $た^{67,68)}$.

一対の滴下水銀電極の毛細管の先端をまげて近つ けておく (Fig. 26). 著者はこれを twin dropping mercury electrodes とよんだ。電位差計 $\mathrm{P}$ 交用 い, 広い $\mathrm{Hg}$ pool 電極 $\mathrm{C}$ を対極にして水銀滴 $\mathrm{A}$ ， $\mathrm{B}$ 江等しい分極電压 $\phi$ を加える，電気毛管性極大 の電位在 $\phi_{\text {eem }}$ とし, $E=\varphi-\varphi_{\text {eom }}$ とすると, $E=0$ で水銀表面電荷はゼロである. $E>0, E=0$, $E<0$ はそれぞれ anodic, zero, cathodic polarization 亿相当する ${ }^{16,55}$.

$E$ が正加負の大きい値のときは生長する滴 $\mathrm{A}$ 上 $\mathrm{B}$ の間の静電兏力が強く, 従って両者の表面が接触 すると別々に落下し，次に新らしい滴が生長し始める. こてに接触とは“肉眼的にふれ合ったと見える”という 意味である。しかし $E=0$ をはさんだある電位領域 $E_{4}$ $>E>E_{-}$では $\mathrm{A}$ と $\mathrm{B}$ が接触すると一つの大きな滴に合 一し，乙れが生長をつづけて最後化落下する（Fig. 27). この現象を肉服で観察できるが，Fig. 26 のACブリッ ジを用いて，合一したために滴下周期が急に長くなる critical な電位を求めて $E_{+}$と $E_{-}$を測定できる.

$E_{+}$と $E_{-}$を溶液のイオン濃度 $c_{e}(\mathrm{M} / \mathrm{l})$ の対数の関 数として表わすと Fig. 28 の曲線がえられる。 $\left|E_{+}\right|$と $\left|E_{-}\right|$は共に $\log c_{e}$ の增加関数で, 曲線の位置はカチオ ンとアニオンの種類に支配される. $E_{+}$はアニオン， $E_{-}$ はカチオンに特有で，かつイオンがちがってあ原子価が 同じなら同一曲線にのっている，また，原子価が同じな

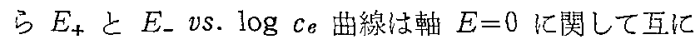
鏡像の関倸にある。

コロイドの凝集条件と水銀滴の 合一条件が同じであ ると仮定するなら，上の寒験事害はまさに SchulzeHardy の法則に合致する。，さらに，Stern 電位 $\psi_{1}$ が 表面の電位 $\psi_{0}$ に平行して変化すると仮定するなら（す

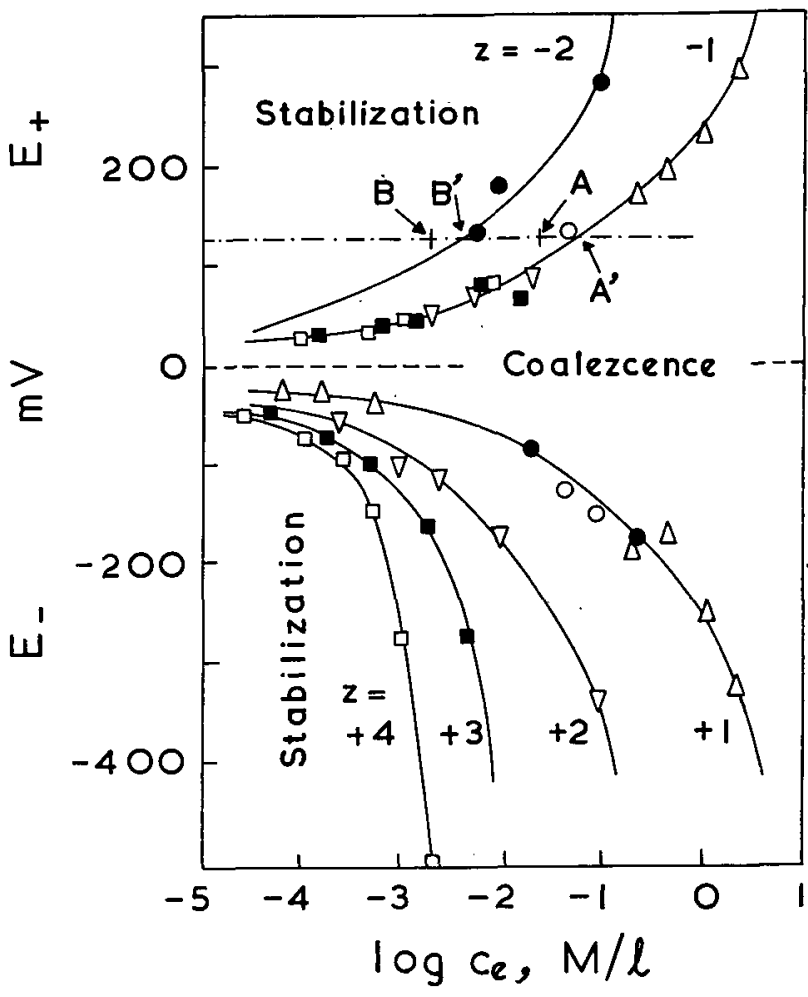

Fig. 28 Critical potential vs. log concentration curves for the coalescence of mercury droplets.

$\triangle \mathrm{KCl} ; \bigcirc \mathrm{KF} ; \mathrm{Na}_{2} \mathrm{SO}_{4} ; \nabla \mathrm{Zn}\left(\mathrm{NO}_{3}\right)_{2}$

- $\mathrm{La}\left(\mathrm{NO}_{3}\right)_{3} ; \square \mathrm{Th}\left(\mathrm{NO}_{3}\right)_{4}$.

$\mathrm{A}, \mathrm{B}$, the coagulation concentrations for the positive silver iodide sol, $\zeta=+130 \mathrm{mV} ; \mathrm{A}^{\prime}, \mathrm{B}^{\prime}$, the concentrations of mono- and divalent anions, corresponding to the critical potential $E_{+}=130 \mathrm{mV}$.

なわち特買イオン吸着がないなら)，吸荺凝集の法則に む一致し，従って Fig. 28 は一般凝集理論を表現して いるととになるすすなわち，滴の電位が正（又は負）の ときの合一条件はアニオン (又はカチオン) の原子価 に支配され，原子価が大きい经ど低濃度で合一が起る (Schulze-Hardy)，滴の電位の維刘值が大きいほど合 一の起るイオン濃度の下限（凝集濃度に相当する）流 い值隹る。また，電解質濃度が一定なら， $E=0$ を中 心に $E_{+}>E>E_{-}$のみで合一分起る (吸着凝集).

Fig. 28 の各曲線は V.3 の急速凝集の起る凝集濃度 を与える条件に刘応している，両者が一致し，加 $\psi_{1}=E$ 之仮定する．今の場合は $c_{e}$ が一定で $E$ を变化さ せるから，式 (69) を満足する $E$ の值が $E_{+}$又は $E_{-}$であ る. 式(50)上り

$$
\log c_{e}=4 \log \gamma-6 \log z+\log B
$$

あるい㤝，式(71)，(72)より

$\left|E_{ \pm}\right|$が小さいとき

$$
\log \left|E_{ \pm}\right|=\frac{1}{4} \log c_{\Theta}+\frac{1}{2} \log z-\log B^{\prime}
$$

$\left|E_{ \pm}\right|$が大きいとき 


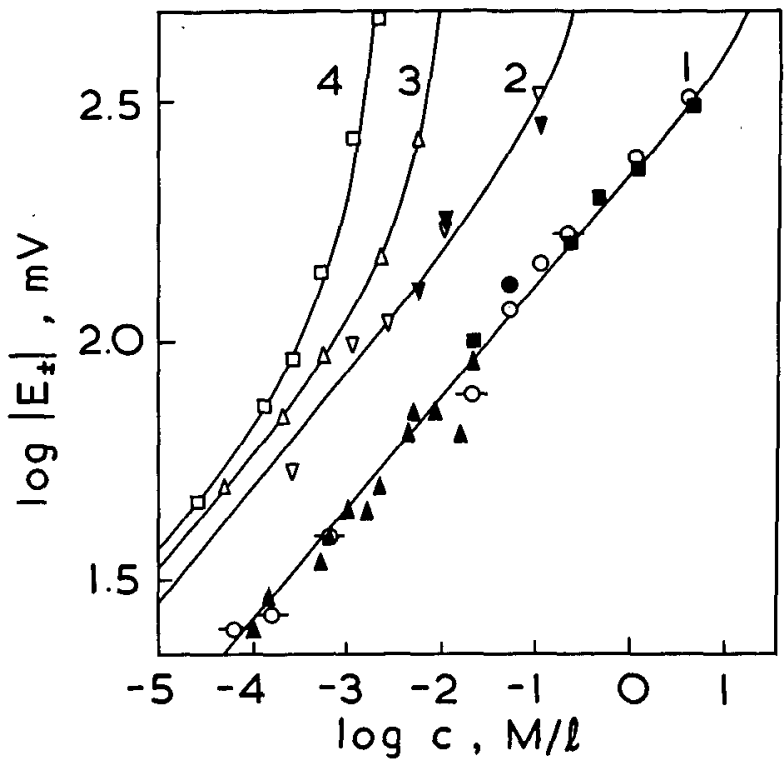

Fig. 29 Log critical potential vs. log ionic concentration curves for simple inorganic electrolyte solutions.

$\mathrm{OK}^{+} ;-\mathrm{O}^{-\mathrm{Na}^{+}} ; \nabla \mathrm{Zn}^{++} ; \triangle \mathrm{La}^{+++} ; \square \mathrm{Th}^{++++}$; - $\mathrm{F}^{-} ; \mathrm{Cl} \mathrm{Cl}^{-} ; \boldsymbol{\Delta} \mathrm{NO}_{3}^{-} ; \nabla \mathrm{SO}_{4}^{--} ; 1,2,3,4$, the absolute values of ionic valencies.

$\log c_{e}=-6 \log z+\log B^{\prime \prime}$

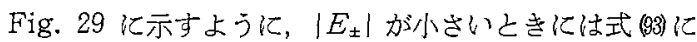
一致して $\log \left|E_{ \pm}\right|$vs. $\log c_{e}$ は勾配1/4の直線となり， $\left|E_{ \pm}\right|$がますと式 (94) に一致して $E_{ \pm}$には依存せず $z$ のみ 隹存する $c_{e}$ 值渐近している。 さらに， $\log c_{e} v s$. $\log z$ は $\left|E_{ \pm}\right|$が大きいと勾配-6の 直線之なり， $E_{ \pm} \mid$が小さい之勾配-2 の直線 となって式 (93)，(94) とよく一 致することす確加りら机た。

汃くて，単純な無機電解質水溶液 中の水銀滴の合一現象が跎液性コ口 イドの凝集理諭によって定量的核説 明できた，すなわち，踈液性コロイ ド粒子間の相互作用注巨視的な水銀 滴間の相互作用之本質的には同じて あり，とすに電気二重層理論を基䃈 にした静電斥力と van der Waals 引力によって説明できることが実験 的に証明できた。逆に，てのことは 界面们招的る二重層の存在の証明に るなっている上思われる。

2 保護作用

血液や牛乳の凝固防ぐのにクエ ン酸壏が有効であるが，踒水性ゾル に执いても同棣なこの塭による安定 化が認められる. Fig. 18 の正 AgI
ゾル（pAg 3）に㧍けるクエン酸ナトリウムの $\log W$ vs. $\log c_{e}$ 曲線は $c_{e}>c a \cdot 10^{-5} \mathrm{M} / 1$ の濃度領域で $\log$ $W$ の增大，すな抢安定化 (stabilization)，を示し

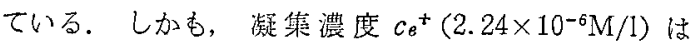
Schulze-Hardy の法則から 3 洒アニオンに予想さ机る 值 $\left(\sim 10^{-4} \mathrm{M} / \mathrm{l}\right)$ 上りはるか代低い。

このような安定化の機構は十分明らかではないが，水 銀滴の合一実験の 結果は頗る暗示的である ${ }^{67,68)}$ ．Fig. 30 はクエン酸ナトリウム水溶液に㧈ける $E_{ \pm} v s . \log c_{e}$ 曲線である。 まず， E - vs. $\log c_{e}$ 注正常な1洒力チオ ンの曲線に一致し， $\mathrm{Na}^{+}$に支配されているてとは明ら かである。これに反して，3価クエン酸アニオンに支配

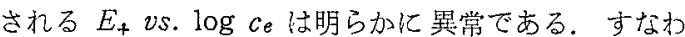
ち, $\log c_{e}<-3.2$ で结成程 $E_{+}$は $\log c_{e}$ の增加関数 ではあるが，この位置は正常な 3 洒アニオンの曲線（曲 線-3）よりずっと低濃度側代ずれている。乙れはおこら くクエン酸イオンの特異吸着によって $\psi_{1}$ が表面の電位 $\psi_{0}(=E)$ より負にずれているためであるう.

さらに著しい特長は，曲線が $\log c_{e} \cong-3.2$ で極大老 示し, $\log c_{e}>-3.2$ で $\log c_{e}$ の減少関数となると之 である。すなわち， 約 $10^{-3} \mathrm{M} / 1$ 以上の浱度で安定化加 起ってい\%。こ机はFig. 18 と全く類似した傾向之云 える.

このような安定化の機構は十分解明されてはいない が，招そらくある種のクエン酸塩の界面膜による保護作

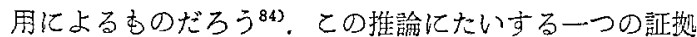

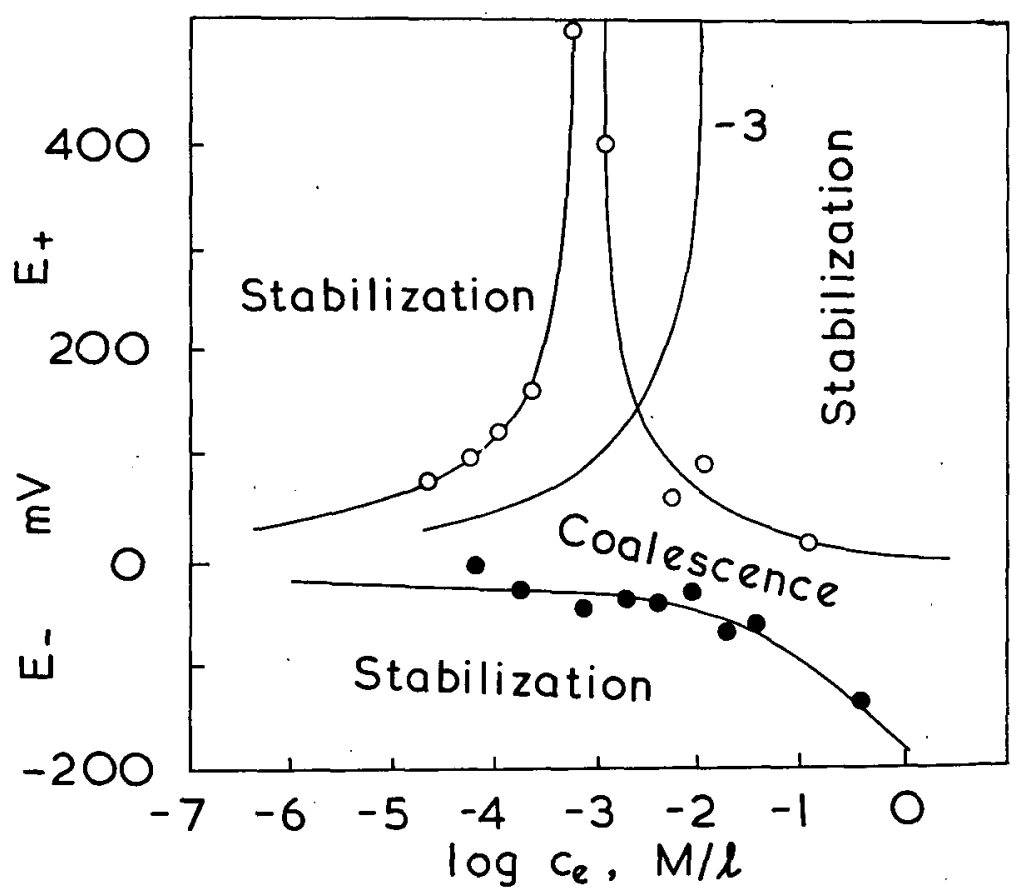

Fig. 30 Critical potential vs. log ionic concentration curves for sodium citrate solutions. 


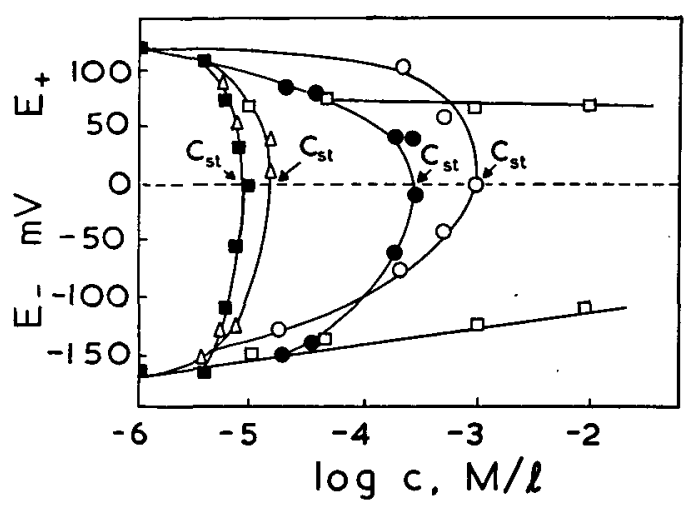

Fig. 31 The effect of various agents on the coalescence of twin dropping mercury electrodes. Supporting electrolyte, $10^{-1} \mathrm{M} / 1 \mathrm{KCl}$.

Dolyvinyl alchol $(\overline{\mathrm{P}}=1,400), \triangle$ Epan (copolymer of ethylene oxide and propylene oxide); SDS; O Cetylpyridinium chloride; $\square$ Glycine.

は Fig. 31 に示す界面活性物質や高分子物質などの添 加による水銀滴合一実験の結果である。乙れは $10^{-1} \mathrm{M} / 1$ $\mathrm{KCl}$ を支持塩にして，その上に種々蕽度 $c$ の添加物が ふくまれている水溶液中での $E_{ \pm} v s . \log c$ 曲線であ る. 中性での Glycine を除くと，而る臨界濃度 $c_{s t}$ を こえると $E$ を如何にゼロに近づけても滴の合一が見ら れず，強力な安定化（保謴作用）が起っている，Cst は 添加物の種類に依存むるが，各種の Epan (ethylene oxide 亡 propylene oxide をふくんだ高分子分散剂) についての合一実験によると, $\log c_{s t} v s . H L B$ は直線 性を示し，HLB が大きくて親水基の含量が大きいほど 低濃度で安定化が起ることがわかった，又二重層微分容 量の測定加ら安定化と吸着量上の関連性屯示された ${ }^{69}$.

\section{むすび}

踈液性コロイドの奥機電解質, 有機界面活性剂, 高分 子物質などによる凝集においては系の性質に従って種々 の凝集様式汃見られる。しかす分散系の灌度, 凝集剂の 濃度, 共存電解質の有無上その濃度, 分散媒の条件 (た とえば $\mathrm{pH} や \mathrm{pAg}$ )など種々の因子がそ机ぞれ著しい 影響を与える。一くちに凝集之呼ばれる現象も広大で複 雑な様相をふくんでおり, その系統的な分類と研究はま だ緒についたばかりと云えるだろう ${ }^{85,867}$ 。乙こには最近 にお河る研究の進歩が著しく, ある程度統一的な見地に 立って論じることが可能となった䟢液性コロイドの凝集 現象を，著者らが行なった理諭的ならびに実験的研究を 中心に述べた次第である.

終りに，この研究に関し多々御教えを賜わった京都大 学化学研究所, 後藤廉平教授, また, Cambridge 大学 の Department of Colloid Science に拈いて 2 年間想 切な御指尊を賜わった現在 Bristol 大学, Department of Chemistry の R. H. Ottewill 愽士に哚く謝意を表
する。なお本稿の執管は本会会長岩瀬慶三先生のおすす めによるもので，ここに記して厚く感謝する次第であ る.

\section{文献}

1) K. J. Mysels: "Introduction to Colloid Chemistry", Interscience, New York (1959).

2) H.R. Kruyt: "Colloid Science 2", Elsevier, Amsterdam (1949).

3) H.R. Kruyt: "Colloid Science 1", Elsevier, Amsterdam (1952).

4) M. Smoluchowski: Physik. Z., 17, (1916) 557, 586.

5) J. Crank: "Mathematics of Diffusion", Oxford Univ. Press, London (1956).

6) A. Einstein: Ann. Physik, 17, (1905) 549 ; 19 , (1906) 371.

7) E.A. Guggenheim: "Thermodynamics", North Holland, Amsterdam (1957) 373.

8) O. Stern: Z. Elektrochem., 30, (1924) 508.

9) J. Lyklema: Trans. Faraday Soc., 59, (1963) 418.

10) D.L. Chapman: Phil. Mag. (6) 25, (1913) 475.

11) L. Gouy: J. Physique (4) 9, (1910) 457; Ann. Physique (9) 7, (1917) 129.

12) N. K. Adam: "Physics and Chemistry of Surfaces", Oxford Univ. Press, London (1941).

13) J.A.V. Butler: "Electrocapillarity", Methuen, London (1939); "Electrical Phenomena at Interfaces", Methuen, London (1951).

14) D. C. Grahame: Chem. Revs., 41, (1947) 441.

15) R. Parsons: "Modern Aspects of Electrochemistry 1", (ed. by O'M Bockris) Butterworths, London (1954).

16）渡边昌, 上田静男：電化， 20 (1952) $247 ， 308 ， 358$ ， 419 .

17) P. Debye, E. Hückel: Physik. Z., 24, (1923) 184, 305.

18) E.J. Verwey, J. Th. G. Overbeek: "Theory of Stability of Lyophobic Colloids", Elsevier, Amsterdam (1948).

19) A. L. Loeb, J. Th. G. Overbeek, P. H. Wiersema: "The Electrical Double Layer around a Spherical Colloid Particle", M.I.T. Press, Cambridge, Mass. (1960).

20) A. Watanabe: Bull. Inst. Chem. Res., Kyoto Univ., 38, (1960). 235.

21) F. Booth: J. Chem. Phys., 19 (1951) 391, 1327, 1651.

22) B. E. Conway, J. O'M Bockris, A. Ammar: Trans. Faraday Soc., 47, (1951) 756.

23) D. C. Grahame: J. Chem. Phys., 18, (1950) 903.

24) M. Eigen, E. Wicke: Z. Elektrochem., 56, (1952) 551 ; J. Physic. Chem., 58, (1954) 703.

25) V. Freise: Z. Elektrochem., 56, (1952) 822.

26) H. Brodowsky, H. Strehlow: ibid., 63, (1959) 262.

27) 渡辺昌, 辻福䓓, 上田静男：電化, 29 (1961) 701, 777.

28) A. Watanabe, F. Tsuji, S. Ueda: Kolloid Z., 191, (1963) $147 ; 193$ (1963) 39.

29) R. H. Ottewill, M.C. Rastogi, A. Watanabe: Trans. Faraday Soc., 56, (1960) 854.

30) A. Watanabe: Bull. Inst. Chem. Res., Kyoto Univ., 38 (1960) 158.

31) J. T. Davies, E. K. :Rideal: "Interfacial Phenomena", Acad. Press, London (1961). 
32) A. Watanabe, F. Tsuji, S. Ueda: Proc. 2nd Intern. Congr. Surface Activity, 3, (1957) 94.

33) I. Langmuir: J. Chem. Phys., 6, (1938) 893.

34) F. Booth: Disc. Faraday Soc., 18, (1954) 104.

35) B. V. Derjaguin: ibid., 18, (1954) 85; Trans. Faraday Soc., 36, (1940) 203.

36) S. Levine, G.P. Dube: Trans. Faraday Soc., 36, (1940) 215.

37) F. London: Z. Physik, 63, (1930) 245.

38) J. C. Slater, J. G. Kirkwood: Phys. Revs., 37, (1931) 682

39) J. Th. G. Overbeek, M. J. Sparnaay: Disc. Faraday Soc., 18, (1954) 12.

40) B.V.Derjaguin, A.S. Titijevskaia, I. I. Abricossova, A. D. Malkina: ibid., 18, (1954) 24.

41) H. C. Hamaker: Physica, 4, (1937) 1058.

42) S. Chandrasekhar: Rev. Modern Phys., 15, (1943) 1.

43) J.Q. Umberger, V.K. La Mer: J. Amer. Chem. Soc., 67, (1945) 1099.

44) N. Fuchs: Z. Physik, 89, (1934) 736.

45) P. Debye: Trans. Electrochem. Soc., 82, (1942) 265.

46) H. Freundlich: Z. physik. Chem., 44, (1903) 129 ; 73, (1910) 385 .

47) H. Freundlich, G. von Elissaf off : ibid., 79, (1912) 385.

48) W. B. Hardy : Proc. Roy. Soc., 66, (1899) 1100 ; J. Phys. Chem., 4, (1900) 235; Z. physik. Chem., $33,(1900) 385$.

49) H. Schulze: J. prakt. Chem. (2) 25, (1882) 431 ; 27, (1883) 320 .

50) H. Reerink, J. Th. G. Overbeek : Disc. Faraday Soc., 18, (1954) 74 .

51) G. H. Jonker, H. R. Kruyt: ibid., 18, (1954) 170.

52) A. Watanabe: Bull. Inst. Chem. Res., Kyoto Univ., 38, (1960) 216.

53) R.H. Ottewill, A. Watanabe: Kolloid Z., 171 , (1960) 33.

54) R. H. Ottewill, A. Watanabe: ibid., 170, (1960) 38.

55）上田静哥, 渡辺昌 : 実験化学講座 7, 丸善 (1956) 386 .

56) G. E. van Gils, H. R. Kruyt: Kolloid Beih., 45, (1937) 60.

57) S. A. Troelstra, H. R. Kruyt: Kolloid Z., 101, (1942) 182.

58) J. Th. G. Overbeek: Kolloid Beih., 54, (1943) 287.

59) D. C. Henry : Proc. Roy. Soc. (London) A, 133 (1931) 106.
60) A. Watanabe: Bull. Inst. Chem. Res., Kyoto Univ., 38, (1960) 179.

61) R.H. Ottewill, A. Watanabe: Kolloid Z., 170, (1960) 132.

62) P. Mukerjee, K. J. Mysels, C. J. Dulin: J. Phys. Chem., 62, (1958) 1390, 1937, 1400.

63) R.H. Ottewill, A. Watanabe: Kolloid Z., 173, (1960) 122

64) G. Oster: J. Biol. Chem., 190, (1951) 55.

65) A. Watanabe: Bull. Inst. Chem. Res., Kyoto Univ., 38, (1960) 248.

66) I. M. Klotz: "The Proteins 1", (ed. by Neurath and Bailey), Acad. Press, New York (1953).

67）後藤廉平, 渡辺昌：日化，84，(1963） 480 .

68) A. Watanbe, R. Gotoh: Kolloid Z., 191, (1963) 36.

69）渡辺昌，松本陸朗，後藤廉平：未発表。

70) J.T. Edsall, J. Wyman: "Biophysical Chemistry 1", Acad. Press, New York (1957).

71) H.C. Hamaker: "Hydrophobic Colloids," Amsterdam (1938) 16; Rec. trav. chim., 55, (1936) 1015; 56 , (1937) 3.

72) H. R. Kruyt, M.A.M. Klompé : Kolloid Beih., 54, (1942) 484

73) A. Kuhn: "Kolloidchemisches Taschenbuch", Akad. Verlags., Leipzig (1960).

74) J. Lyklema, J. Th. G. Overbeek : J. Colloid Sci., 16, (1961) 501.

75) J. W. Mitchell: Lecture at the Univ. of Cambridge, England (1959)

76) R.H. Ottewill, J.A. Sirs: Bull. Photoelectr. Spectrometry Group, 10, (1957) 262.

77) R. W. Horne, R. H. Ottewill, A. Watanabe: Proc. 3rd Intern. Congr. Surface Activity, 1, Cologne (1960) 203

78) R. H. Ottewill, A. Watanabe: Kolloid Z., 173, (1960) 7 .

79) E. J. Verwey: Chem. Revs., 16, (1935) 363.

80) S. Hachisu, K. Furusawa: Science of Light, 12, (1963) 1 .

81) M. B. M'Ewen, M. I. Pratt: Trans. Faraday Soc., 53, (1957) 535; M. B. M'Ewen, D. L. Mould, ibid, 53, (1957) 548.

82) R. N. Gurney: "Ionic Processes in Solution", McGraw-Hill, New York (1953).

83) R. H. Ottewill, M.C. Rastogi : Trans. Faraday Soc., 56, (1960) 866, 880.

84) P. Becher: "Emulsions", Reinhold, New York (1957).

85) 渡辺昌：顔料， 7 (1963) 886，915，941.

86）渡辺昌：ポーラログラフィー，10（1962） 175. 